Research paper

\title{
Brand worlds: Introducing experiential marketing to B2B branding
}

\author{
Benjamin Österle ${ }^{\mathrm{a}, \mathrm{b}, *}$, Marc M. Kuhn ${ }^{\mathrm{a}}$, Jörg Henseler ${ }^{\mathrm{b}, \mathrm{c}}$ \\ ${ }^{a}$ Center for Empirical Research, Baden-Wuerttemberg Cooperative State University Stuttgart, Paulinenstr. 50, 70178 Stuttgart, Germany \\ ${ }^{\mathrm{b}}$ Department of Design, Production \& Management, Faculty of Engineering Technology, University of Twente, P.O. Box 217, 7500 AE Enschede, The Netherlands \\ ${ }^{\mathrm{c}}$ Nova Information Management School, Universidade Nova de Lisboa, Campus de Campolide, 1070-312 Lisboa, Portugal
}

\section{A R T I C L E I N F O}

\section{Keywords:}

Brand worlds

B2B

Branding

Experiential marketing

Relationship

Emotion

\begin{abstract}
A B S T R A C T
Experiential marketing instruments and the extraordinary experiences they provide are one of the strongest means of branding in B2C. Inter alia as brand worlds, they also exist in B2B marketing practice, but have only received limited attention from the B2B branding perspective. Differences between B2C and B2B branding raise questions regarding why $\mathrm{B} 2 \mathrm{~B}$ companies operate brand worlds, what they consist of, what their nature is, and how they are experienced. We build on a rich, comprehensive sample of 37 expert interviews, comprising the perspectives of operating companies, business visitors, and exhibition designers. We find that B2B brand worlds differ substantially from their B2C equivalents in several aspects, but they apply similar experiential techniques. Operating companies' motives focus on providing live product experiences to explain complex products and create product awareness. B2B visitors expect more functional than hedonic benefits, and the visit has to support them in their own business activities. Affordances of the experiencescape and the action-perception between visitor, brand employees, and the physical environment are at the core of how the B2B brand world experiences are co-created. Our research highlights the important role and nature of B2B brand worlds as three-dimensional "business cards", where relationships are initiated and built.
\end{abstract}

\section{Introduction}

Since the introduction of the idea that consumption involves a "steady flow of fantasies, feelings, and fun encompassed by what we call the experiential view" (Holbrook \& Hirschman, 1982, p. 132), the concept of customer experience has played a crucial role for both marketing practitioners and academics. Experiential marketing refers to the strategies of staging and creating offerings for the purpose of facilitating extraordinary experiences (Carù \& Cova, 2003; Pine \& Gilmore, 1999). Customer experiences with brands along all touchpoints and branding instruments are crucial to the branding process, whether extraordinary or not (Brakus, Schmitt, \& Zarantonello, 2009). The value of the experience is co-created, and the result of interactions between a single firm or a brand - the experience provider - and the customer, but also between a whole network of firms, employees, brands, experts or opinion leaders and this customer (Tynan \& McKechnie, 2009). Reciprocally, brands play an important role in this process of experience co-creation (Tynan \& McKechnie, 2009). Differentiation, a main driver of experiential marketing, is a crucial function of brands in both B2C and B2B (Kotler, Pfoertsch, \& Michi, 2006), and brands themselves are rich sources of "sensory, affective, and cognitive associations that result in memorable and rewarding brand experiences" (Schmitt, 1999a, p. 57). A specific branding instrument which uses experiential marketing techniques, the flagship store, is called the "apex of branding" (Dolbec \& Chebat, 2013, p. 460). But also other instruments of branding, for example permanent, physical branded locations such as brand lands, brand museums, or customer experience centers, which we summarize with flagship stores under the umbrella term "brand worlds", deliver powerful branded experiences much stronger than regular advertising, based on their direct, highly interactive visitor-brand encounters and experiential marketing techniques (Borghini et al., 2009; Wood, 2009; Zarantonello \& Schmitt, 2013). Indisputably, this holds true for the emotional realm of consumer marketing. There can hardly be a greater achievement for a brand than fully materializing in its own successful brand world, such as the Walt Disney World, the World of Coca-Cola, the Hershey Park, the VW Autostadt or the Apple Flagship Stores.

Since branding in B2B increasingly attracts attention (Keränen, Piirainen, \& Salminen, 2012; Leek \& Christodoulides, 2011; Seyedghorban, Matanda, \& LaPlaca, 2016), the question arises which role experiential marketing and its techniques play in this context. Its instruments and techniques have been mentioned as a possibility for B2B companies to create strong, memorable customer experiences (Gilmore \& Pine, 2002; Pine \& Gilmore, 1999; Schmitt, 1999b), but

\footnotetext{
* Corresponding author at: Center for Empirical Research, Baden-Wuerttemberg Cooperative State University Stuttgart, Paulinenstr. 50, 70178 Stuttgart, Germany.

E-mail addresses: benjamin.oesterle@dhbw-stuttgart.de (B. Österle), marc.kuhn@dhbw-stuttgart.de (M.M. Kuhn), j.henseler@utwente.nl (J. Henseler).
} 
only trade shows have been investigated from an experiential perspective on business markets, and without a branding perspective (Rinallo, Borghini, \& Golfetto, 2010). This gap in research can be explained with the predominant notion of rational and professional actors in the business context, as opposed to the original experiential value sources of "fantasies, feelings, and fun" (Holbrook \& Hirschman, 1982, p. 132). Trade show experiences create value first and foremost when they support the B2B visitors in their business activities, "no matter how entertaining or spectacular they may be" (Rinallo et al., 2010, p. 256). This preliminary understanding of experiential marketing in business markets is followed by a call for further research on other experiential marketing instruments and the determinants of their effectiveness (Rinallo et al., 2010). Nevertheless, industrial marketing practitioners have already discovered the branding potential of experiential marketing techniques. B2B brand worlds can in fact be found all over the planet, such as for example the Caterpillar Visitors Center or the Customer Experience Centers of General Electric and Honeywell Process Solutions in the US, the Innovation Center of logistics provider DHL or the Stahlwelt of Austrian steel producer Voestalpine in Europe, or the Mitsubishi Minatomirai Industrial Museum in Asia. But in contrast to their B2C counterparts, these instruments of branding, which employ experiential marketing techniques, have not attracted academic attention yet (Österle, Kuhn, \& Henseler, 2016).

Against this background, this article enriches B2B branding research with a new theoretical perspective, experiential marketing, and examines brand worlds as a branding instrument that uses experiential marketing techniques. Given the dyadic nature of experiences (Lemon \& Verhoef, 2016), we adopt both an organizational and a customer perspective, and complement these with the perspective of exhibition designers. In order to understand brand worlds and their use of experiential marketing techniques for B2B branding, the goal of this study is threefold. First, to answer the question of why, to investigate the motives of industrial companies to implement brand worlds, to identify expectations $\mathrm{B} 2 \mathrm{~B}$ visitors have, and the value they derive from the experience of a B2B brand world visit; second, to answer the question of what, to understand the nature of the B2B brand world and what it is constituted of; and third, to answer the question of how, to investigate how the B2B brand world is perceived and how the experience is cocreated.

This paper contributes in several ways. It provides a theoretical contribution by introducing brand worlds as an instrument of branding, which employs experiential marketing techniques, to the B2B context. As such, it also provides a contextual contribution and expands the B2B literature on brand building tactics and brand management. We also identify brand worlds as locations for operating companies and business visitors to personally interact and build relationships during the entire customer journey, contributing to the relationship and interaction approaches in B2B. Brand worlds also convey customer value propositions with the hands-on product experiences they evoke, as well as other experiential value dimensions. Thus, our research contributes to the current discussion on value in business markets. Fifth, by taking a phenomenological stance of embodied cognition, our paper also contributes to the understanding of how experiences in brand worlds are perceived and co-created.

The remainder of this paper is structured as follows. To provide the setting for this study, we outline the differences between B2C and B2B branding, and elaborate on brand worlds as instruments of branding which employ experiential marketing techniques. We then outline experiential marketing and experiential value, as well as the phenomenological perspective we took in order to understand the nature of B2B brand worlds and how they are experienced. Next, we describe our exploratory research approach, and present an overview of our comprehensive, multi-perspective sample. Subsequently, we present our results. We conclude with a discussion of our findings, provide areas for future research and implications for theory and practice, and outline the limitations of our study, before giving an outlook on brand worlds in $\mathrm{B} 2 \mathrm{~B}$.

\section{Theoretical background}

\subsection{Differences between $B 2 C$ and $B 2 B$ branding}

Key differences of B2B markets relative to $\mathrm{B} 2 \mathrm{C}$ include the nature of demand (derivative vs. primary); a culture driven by manufacturing and technology, which is related to the complexity of industrial products; more technical and quantifiable value propositions; a small number of customers, but large-unit transactions; complex buying processes involving buying centers and thus group dynamics, resulting in more rational discourse and decision-making; the emphasis on corporate rather than product branding; and the more important role of relationships, interpersonal communication or personal selling (Brown, Bellenger, \& Johnston, 2007; Brown, Zablah, Bellenger, \& Donthu, 2012; Grewal, Krishnan, Baker, \& Borin, 1998; Kotler et al., 2006; Lilien, 2016; Webster \& Keller, 2004; Zablah, Brown, \& Donthu, 2010). B2B buying decisions are influenced by the buying situation (e.g. Kotler et al., 2006), a higher perceived risk, and the more economic and performance type of risk (Brown et al., 2007). These general differences have effects on marketing communications, which are proposed to be more technical and pedagogical, but also more interactive and personal, and thus also on the branding efforts on business markets (Brown et al., 2007).

When it comes to brands, things were supposed to be different in industrial marketing. For a substantial period of time, branding was not relevant, and a pure B2C phenomenon (Kotler et al., 2006). After about 40 years of research, however, B2B branding has evolved from irrelevance towards being important for business marketing practice, and an established field of study (Gordon, Calantone, \& Di Benedetto, 1993; Interbrand, 2016; Saunders \& Watt, 1979; Seyedghorban et al., 2016; Shipley \& Howard, 1993; Sinclair \& Seward, 1988; Webster \& Keller, 2004). Nowadays, "branding is just as relevant in B2B as it is in B2C" (Kotler et al., 2006, p. 12). In the course of this evolution, many concepts, frameworks, and theories have been transferred and adapted from the further developed consumer to the industrial context (e.g. Beverland, Napoli, \& Lindgreen, 2007; Kuhn, Alpert, \& Pope, 2008; Mudambi, Doyle, \& Wong, 1997). Researchers have to be cautious with this transfer and take into account the unique characteristics of B2B markets for the development of a sound B2B branding theory (Keränen et al., 2012; e.g. Mudambi, 2002; Seyedghorban et al., 2016; Webster \& Keller, 2004).

Both academics as well as practitioners today acknowledge that industrial brands serve similar general purposes as consumer brands (Keränen et al., 2012; Kotler \& Pfoertsch, 2007; Wise \& Zednickova, 2009). They are means of identification, differentiation, and employer branding, ambassadors towards all stakeholders, indicators of origin, quality, and performance, thus reducing risk and complexity of buying decisions, and they are means to communicate the values and benefits of a company's offerings - even increasing the perceived value of a product for a customer (Bengtsson \& Servais, 2005; Cretu \& Brodie, 2007; Davis, Golicic, \& Marquardt, 2008; Kotler et al., 2006; Kotler \& Pfoertsch, 2007; Leek \& Christodoulides, 2011; Leischnig \& Enke, 2011; Michell, King, \& Reast, 2001; Ohnemus, 2009; Wise \& Zednickova, 2009; Zablah et al., 2010). B2B brands also have financial value for the company. They help to attract customers, to get on bid lists, to shift tight purchasing decisions in a desired direction, and increase customer loyalty (Ohnemus, 2009; van Riel, de Mortanges, \& Streukens, 2005; Wise \& Zednickova, 2009). Brand-loyal industrial buyers in turn promote the brand to other purchasing agents, consider the brand's other products, and even pay a price premium for their favorite brand, leading to higher sales turnovers (Bendixen, Bukasa, \& Abratt, 2004; Hutton, 1997). To summarize, despite their importance is context-dependent (Brown et al., 2012; Zablah et al., 2010), brands matter to business buyers (Cretu \& Brodie, 2007; Mudambi, 2002). As in B2C, 
brand value in B2B comprises not only functional and rational components such as quality, technology, and reliability, but also emotional and hedonic components such as risk reduction, reassurance, trust, and credibility (Brown et al., 2012; Gomes, Fernandes, \& Brandão, 2016; Leek \& Christodoulides, 2012; Lynch \& Chernatony, 2007). Yet as opposed to B2C, the most important brand values in B2B are functional ones, whereas emotional aspects play a minor role (Backhaus, Steiner, \& Lügger, 2011; Leek \& Christodoulides, 2012).

When it comes to the question of how a B2B brand can be built and communicated, the brand is conceptualized as a holistic and interactive experience, as in B2C (Ballantyne \& Aitken, 2007; Biedenbach \& Marell, 2010; Kotler et al., 2006; Lynch \& de Chernatony, 2004). Therefore, despite the specific importance of the salesperson and personal interaction (Lynch \& Chernatony, 2007), all customer touchpoints and elements of the marketing mix contribute to brand equity dimensions, as they do in B2C: They create awareness of the brand, link desired associations to the brand image, evoke emotions or judgements of quality, and facilitate a stronger customer-brand relationship (Biedenbach \& Marell, 2010; Kotler et al., 2006). These differences between - but also the similarities of $-\mathrm{B} 2 \mathrm{C}$ and B2B branding provide the context of our study of brand worlds as instrument of branding and its use of experiential marketing in B2B.

\subsection{Brand worlds}

Due to the lack of research and literature on brand worlds in the B2B context, on which we focus in our study, we provide background information on their B2C counterparts in this section as starting point for our investigation. Brandscaping - creating physical locations based on brands - is one of the strongest means in branding in B2C, based on emotions and a non-rational, experiential approach (Riewoldt, 2002). Practical examples for these physical locations based on brands in B2C are the Disney Worlds, the Apple flagship stores, or the World of CocaCola in Atlanta, Georgia, to only name a few. They follow the conviction that "the glamour and power of the brand are the key weapons in the battle for target groups and customers. By staging the brand experience in flagship stores, shop designs or entire theme parks, companies communicate the image of the brand and imprint a characteristic atmosphere on the consumer consciousness" (Riewoldt, 2002, p. 8). In such locations, in contrast to most classical advertising instruments, the brand becomes visible, actually tangible, and therefore a strong, real, memorable customer experience and relationship between the brand and the customer is created (Manlow \& Nobbs, 2013; Webb, 2012). The live experience of taking a trip to, for example, a brand park, and actually visiting the brand becomes part of one's own life and has a higher recollective value than simple advertising or conventional PR (Mikunda, 2004). Simply witnessing a product's production in a mere plant tour can lead to higher brand loyalty, based on the identification with the product, the familiarity with the production process, and the interaction with employees (Mitchell \& Orwig, 2002).

Flagship stores are titled the "apex of branding" because of their branding power (Dolbec \& Chebat, 2013, p. 460). Similar venues have been mentioned and investigated in consumer-centric academic literature, such as customer experience places, brand lands, brand museums, brandscapes, flagship stores etc. (Borghini et al., 2009; Diamond et al., 2009; Gilmore \& Pine, 2002; Hollenbeck, Peters, \& Zinkhan, 2008; Joy, Wang, Chan, Sherry Jr, \& Cui, 2014; Kozinets et al., 2002; e. g. Sherry Jr., 1998; Sherry Jr et al., 2001). The terms partially overlap and lack clear distinctions and definitions (Österle et al., 2016). Therefore, we use the term 'brand worlds' as an umbrella term for such permanent branded locations that are an instrument of brand communication and experiential marketing. These brand worlds have been subject to a limited amount of academic research in the B2C environment already. For example, the goals of different types of brand worlds in various industries have been investigated, which are, to summarize, related to the image of the brand, the presentation, staging and test of products,
Table 1

Main goals for the implementation of brand worlds in B2C (adapted from Kirchgeorg et al., 2012; Zentes et al., 2014).

\begin{tabular}{llc}
\hline Highest priority & Medium priority & Lower priority \\
\hline - Brand experience & - Information & $\bullet$ Customer \\
- Brand- and product & $\bullet$ Raising brand & integration into \\
presence & awareness & business processes \\
- Determination of the & $\bullet$ Internal & (e. g. co-creation) \\
own position in the & communication goals & $\bullet$ Engaging with new, \\
competitive & $\bullet$ Management and & potential customers \\
environment & activation of existing & $\bullet$ Generating sales \\
- Improve, strengthen & customer relationships & turnover \\
and foster the brand & $\bullet$ Building trust & \\
image & & \\
\hline
\end{tabular}

customer relationship goals, merchandising goals, and knowledge transfer (Borghini et al., 2009; Diamond et al., 2009; Gilmore \& Pine, 2002; Hollenbeck et al., 2008; Joy et al., 2014; Kozinets et al., 2002; e.g. Sherry Jr., 1998; Sherry Jr et al., 2001). Further main goals with different priorities were identified for brand worlds, as depicted in Table 1.

B2C visitors' expectations and demands have also been subject to investigation. When they visit brand worlds, they want to experience entertainment, flow, get information about the products and the brand, relax, be distracted and escape from their day-to-day live, experience community with other visitors, and feel well and appreciated by the operating company (Kirchgeorg, Springer, \& Ermer, 2012; Opaschowski, 2000; Zentes, Ney, \& Keßler, 2014). These expectations and demands are summarized in Table 2.

The different, professional background outlined in section 2.1 suggests, that several differences might arise between brand worlds in B2C and $\mathrm{B} 2 \mathrm{~B}$, regarding both the motives of companies operating a brand world in the B2B context, as well as the expectations that B2B visitors have and the value they derive from the visit of a B2B brand world. Numerous practical examples of B2B brand worlds exist all over the world, implemented by a variety of companies in different industries which have already recognized the branding power of such locations. For example, in the US there are the Mack Trucks Customer Center, the Caterpillar Visitors Center, the Customer Experience Centers of General Electric and Honeywell Process Solutions, the Automation and Power Center of ABB, or the Tomahawk Customer Center of Case Construction. Examples in Europe are the Innovation Center of logistics provider DHL, the Stahlwelt of Austrian steel producer Voestalpine, or the Brand Stores and Flagship Stores of power tool manufacturer Hilti. An example from Asia is the Mitsubishi Minatomirai Industrial Museum.

\subsection{Experiential marketing and experiential value}

The importance of the consumption and customer experience concept is driven by an increasing need for differentiation in a commoditized world (Holbrook \& Hirschman, 1982; Pine \& Gilmore, 1999; Schmitt, 1999a; Schulze, 2005). Customer experience is characterized as a broad and holistic umbrella construct, that encompasses cognitive evaluations, affective responses, social, and physical or sensorial components (Kranzbühler, Kleijnen, Morgan, \& Teerling, 2018; Lemon \& Verhoef, 2016; Verhoef et al., 2009). Customer experiences can be considered as consisting of pre-experience, core experience, and postexperience stages, and being inherently dyadic (Arnould, Price, \& Zinkhan, 2004). They are the result of various degrees of interaction between a single firm or brand and a customer, ranging from those consumption experiences which are independently constructed by consumers, to those experiences that are co-created by companies and consumers, and finally those consumption experiences which are largely "constructed" by organizations (Carù \& Cova, 2007). But also a whole network of firms, employees, brands, experts or opinion leaders can influence the customer experience, and therefore they need to be 
Table 2

Super-ordinate expectations and demands of B2C brand world visitors (adapted from Kirchgeorg et al., 2012; Opaschowski, 2000; Zentes et al., 2014).

\begin{tabular}{|c|c|}
\hline Expectation/demand category & Content \\
\hline Entertainment & $\begin{array}{l}\text { Visitors want to spent a good time and experience something new and extraordinary. The brand world has to offer a high entertainment } \\
\text { value and at the same time differentiate itself from similar marketing formats via extraordinary and new experiences. }\end{array}$ \\
\hline Information & Visitors want to get to know the company, the brand and its products in their own 'living room'. \\
\hline Flow & $\begin{array}{l}\text { If the brand world manages to create a positive immersion in the experience which fascinates the visitors, a consistent experience will } \\
\text { emerge which increases the visitors' involvement in such a way, that they might even lose track of time. }\end{array}$ \\
\hline Relaxation & Visitors expect a relaxed experience which is not straining them. \\
\hline Diversity & $\begin{array}{l}\text { Target groups expect a high infotainment value from the brand world, meaning a diversified, and highly experiential connection between } \\
\text { entertaining and informative elements. }\end{array}$ \\
\hline Escapism & Visitors see a visit to a brand world as welcome distraction from day-to-day life. \\
\hline Community & $\begin{array}{l}\text { Visitors do not want to experience the brand world in isolation, but value a group experience and want to interact and experience the visit } \\
\text { with others }\end{array}$ \\
\hline Sense of well-being and appreciation & $\begin{array}{l}\text { Visitors expect a strong appreciation of their visit and interest in the brand from the operating company. The brand world should thus not } \\
\text { make the impression of a sales tool. Furthermore, visitors want to be welcomed in a clean and tidy environment by well-trained personnel. }\end{array}$ \\
\hline
\end{tabular}

investigated from both the organizational and the customer's perspective (Kranzbühler et al., 2018; Tynan \& McKechnie, 2009). Several research streams focusing on experience have evolved based on different perspectives and meanings of the term experience (for detailed reviews, please refer to Carù \& Cova, 2003; Jain, Aagja, \& Bagdare, 2017; Schmitt \& Zarantonello, 2013). The original 'experiential view' implies that any type of consumption is not only a logical and rational process, but instead involves "a steady flow of fantasies, feelings, and fun" (Holbrook \& Hirschman, 1982, p. 132).

The core idea of experiential marketing is that in today's commoditized world of the experience society and economy, customers perceive functional features and benefits, product quality, and a positive brand image as given. They instead now want products, communications, and marketing campaigns to deliver an extraordinary experience (Pine \& Gilmore, 1999; Schmitt, 1999a; Schulze, 2005). Experiences are subjectively felt emotions that cannot be 'made' or 'guaranteed' by the 'provider'. They depend on the processing and the reception of each individual customer (Kilian, 2009). Experiential marketing thus refers to the strategies of staging and creating offerings for the purpose of facilitating these extraordinary experiences (Carù \& Cova, 2003; Pine \& Gilmore, 1999). For experience providers it is crucial to create an adequate and fitting environment which contributes to the evoking of a desirable experience, and their ability to create, manage, and market these experiences will strongly influence their success (Berry \& Carbone, 2002; Prahalad \& Ramaswamy, 2004; Schmitt, 1999a,b; van Boven \& Gilovich, 2003). Company's brands play an important role in the co-creation of experiences. They are not only mere identifiers facilitating the experience, but rich sources of "sensory, affective, and cognitive associations that result in memorable and rewarding brand experiences" (Schmitt, 1999a, p. 57). These brand experiences are subjective, internal consumer responses to brand-related stimuli, like sensations, feelings, emotions, and cognition (Brakus et al., 2009).

Experiential marketing and its techniques have so far mostly been discussed in the context of consumer markets. This can be explained with the focus on emotions, feelings and hedonic dimensions in B2C, whereas traditionally the $\mathrm{B} 2 \mathrm{~B}$ area is seen as more professional and rational (Rinallo et al., 2010). The existing research on experiential marketing in B2B is mainly limited on trade shows as an important means of B2B communication and event marketing (Kirchgeorg, Springer, \& Kästner, 2010; Rinallo et al., 2010; Zarantonello \& Schmitt, 2013). The findings suggest that in that context, experiential marketing methods and tools developed in B2C can be and are applied in B2B (Rinallo et al., 2010). Since the industrial buyer experiences in trade shows are instrumental, this preliminary understanding of experiential marketing in business markets is followed by a call for further research on other experiential marketing instruments and the determinants of their effectiveness, because some experiential marketing tactics that are based on autotelic activities and involve fantasies, feelings, and fun, and which work in consumer markets, may prove to be ineffective or even counter-productive in industrial environments (Rinallo et al., 2010).

Experiential value is defined as the value derived from an experience via interactions involving either direct usage or distanced appreciation of goods and services (Mathwick, Malhotra, \& Rigdon, 2001). This conceptualization is based on the work of Holbrook (1999), who presented a typology of consumer value, designed to classify the types of value in the consumption experience along three continuous key dimensions: extrinsic vs. intrinsic value, self-oriented vs. other-oriented value, and active vs. reactive value (Holbrook, 1999). Holbrook introduced a relativistic view of consumer value, based on the notions of value being 1) comparative, as it involves a comparison among products and services, 2) personal, as it varies from person to person, and 3) situational, as it depends on the context of the experience (Holbrook, 1999). Largely based on Holbrook's seminal work, different experiential value sources or types have been identified (Gentile, Spiller, \& Noci, 2007; Schmitt \& Zarantonello, 2013; Tynan \& McKechnie, 2009; Varshneya, Das, \& Khare, 2017). We present an overview of experiential value dimensions in B2C, going far beyond fantasies, feelings,

Table 3

B2C experiential value dimensions (adapted from Tynan \& McKechnie, 2009; Varshneya et al., 2017).

\begin{tabular}{|c|c|}
\hline B2C experiential value dimensions & Authors \\
\hline Sensory & Schmitt (1999a,b); Agapito, Valle, and Mendes (2014) \\
\hline Emotional & Schmitt (1999a); Richins (1997); Mathwick et al. (2001); Sweeney and Soutar (2001); Sánchez, Callarisa, Rodríguez, and Moliner (2006) \\
\hline Functional/Utilitarian & Arnould et al. (2004); Mathwick et al. (2001); Sweeney and Soutar (2001); Sánchez et al. (2006) \\
\hline Hedonic & Babin, Darden, and Griffin (1994); Varshneya and Das (2017) \\
\hline Relational & Fournier (1998); Gainer (1995); Lusch, Vargo, and O'Brien (2007); McKechnie and Tynan (2008); Schmitt (1999a); Vargo and Lusch (2008) \\
\hline Social & $\begin{array}{l}\text { Andrews, Kiel, Drennan, Boyle, and Weerawardena (2007)Trevinal and Stenger (2014); Varshneya and Das (2017); Sweeney and Soutar } \\
\text { (2001); Sánchez et al. (2006) }\end{array}$ \\
\hline Cognitive/Informational & Schmitt (1999a); Poulsson and Kale (2004); Varshneya and Das (2017) \\
\hline Novelty & Poulsson and Kale (2004) \\
\hline Utopian & Maclaran and Brown (2005) \\
\hline Ethical & Varshneya and Das (2017) \\
\hline
\end{tabular}


Table 4

B2B experiential value dimensions in networking events (adapted from Mitchell et al., 2016).

\begin{tabular}{|c|c|}
\hline B2B experiential value dimensions & Description \\
\hline Leaning, epistemic, and knowledge & Value based on finding out information and practices to improve activities or solve particular issues. \\
\hline Innovation & $\begin{array}{l}\text { Value which is derived from obtaining access to new markets and technologies, pooling complementary skills, or speeding } \\
\text { products to markets. }\end{array}$ \\
\hline Professional & $\begin{array}{l}\text { A form of functional value which "translates into benefits for the individual within the organization such as: gaining new } \\
\text { customers, business partners, suppliers which are mediated by that individual" (Mitchell et al., 2016, p. 102). }\end{array}$ \\
\hline Reputation & The value organizations or individuals derive from doing business with high equity brands. \\
\hline Social & $\begin{array}{l}\text { Involving socializing and creating connections and relations that enhance the individual's social standing, rather than } \\
\text { professional connections. }\end{array}$ \\
\hline Relationship & $\begin{array}{l}\text { Seen on the individual level as "the value of knowing the person with whom you on behalf of your company are transacting" } \\
\text { (Mitchell et al., 2016, p. 102). }\end{array}$ \\
\hline Emotional & An activation of emotions and feelings for the individuals \\
\hline $\begin{array}{l}\text { Hedonic, altruistic, entertainment, service } \\
\text { excellence }\end{array}$ & Pleasure in the consumption is appreciated as an end in itself and one's consumption behavior influences others. \\
\hline
\end{tabular}

and fun, in Table 3.

Research on experiential value in B2B is limited. Based on both organizational and consumer value literature, recent explorative research in the B2B context examined the value types created in the experience of visiting networking events (Mitchell, Schlegelmilch, \& Mone, 2016). Visitor's perceived value in this event context, which is related to experiential marketing or visiting a brand world, comprise eight dimensions. They are presented in Table 4. These findings are in line with propositions, that a cross-fertilization between value models of B2C and B2B will help to reciprocally fill gaps of understanding. For $\mathrm{B} 2 \mathrm{~B}$, it is suggested to consider the role that emotions and individuals play in all stages of the buying decision process (Kemp, Borders, Anaza, \& Johnston, 2018), and to include more non-rational dimensions in the appreciation of perceived value (Mencarelli \& Rivière, 2015).

Although the possibility for B2B companies to create flagship venues where customer visits can evolve into engaging branded experiences has also been mentioned in the literature (Gilmore \& Pine, 2002), and their emergence in business practice as outlined in section 2.2, they have not so far attracted the attention of academia. To address this gap and understand the nature of this branding instrument and its experiential marketing techniques, how it is experienced and contributes to $\mathrm{B} 2 \mathrm{~B}$, we investigate these brand worlds in the industrial marketing context.

\subsection{Phenomenological background}

In order to investigate and understand the nature of B2B brand worlds and how they are experienced, we draw on the psychological stance of phenomenology, the primary focus of which are the questions of how we perceive, experience, and act in the world around us (Dourish, 2004), and which we therefore deem fruitful for the purpose of our research. Specifically, we focus on the concepts of embodiment and affordances, which we will briefly introduce here. These are not new, but have recently infused research in fields related to brand worlds, such as design (van Dijk, 2018), architectural experiences (Jelić, Tieri, Matteis, Babiloni, \& Vecchiato, 2016), consumer and service experiences (Helkkula, Kelleher, \& Pihlström, 2012; Kelleher \& Peppard, 2011), and customer retail experiences (Yakhlef, 2015).

Current literature on experiences provides a thorough understanding of the internal, psychological, cultural, or environmental factors shaping an experience (Berry \& Carbone, 2002; Bitner, 1990, 1992; Holbrook \& Hirschman, 1982; Verhoef et al., 2009; Yakhlef, 2015). Yet the role of the body, our medium for having a world, and the locus for actions and perceptions through which we relate to, enact, and experience our environment, is unaccounted for, and the body is instead seen as transmission device for perception, "ignoring its potential as the locus of an innovative interactive process between the agent and the environment" (Yakhlef, 2015, p. 554). In contrary to this cartesian dualism of cognitivism, which makes a strong separation between mind and body (Dourish, 2004), taking an embodied perspective means to understand the unified lived body, neither only the physical body nor the mind, as anchoring us in our environment (Merleau-Ponty, 1962). From an embodied perspective, perception, the activity of our sense is not a window to cognition, but a bodily, emotional, and cognitive activity - perceiving is something that we actively do (Merleau-Ponty, 1962; Noë, 2006). Action, in turn, is the activity of our 'motor'-system. Embodiment implies a strong coupling between action and perception which are in constant coordination in the action-perception-cycle, so that the way people actually experience the world is dependent on this dynamic sensorimotor activity of the human organism as a whole (Jelic et al., 2016; van Dijk, 2018). In other words, "perception is for action, and action is for perception" (Cañal-Bruland \& van der Kamp, 2015, p. 63). This perspective makes the body necessary for experiencing the environment, including for example architecture or retail spaces, and emphasizes the intrinsic connection between these environments and human mind/body through action (Jelić et al., 2016; Yakhlef, 2015).

With regard to this action, affordances are defined as possibilities for action which are provided to an 'animal' by its environment, as perceived by this animal (Gibson, 1986). In fields related to design, such as architecture or product design, the term affordances has been used to describe the functionality of designed artifacts in terms of the perceived usability by the user (e.g., the mobility and ergonomic properties of architectural elements and spaces) (Jelić et al., 2016). A further connection between designed affordances as action possibilities that can also invite behavior and the agent's capacities to perceive and engage with them has been put forward more recently than Gibson's original definition (Withagen, de Poel, Araújo, \& Pepping, 2012). Based on this, and the premise that affordances can be designed by e.g. architects or other designers, the suggestion has been made recently that "people's experience of architectural environments is intrinsically structured by the possibilities for action, which is informed from both sensorimotor knowledge and motivational factors of every individual." (Jelić et al., 2016, p. 11).

\section{Methodology}

\subsection{Expert interviews}

Given the exploratory nature of our research question, we applied a qualitative research approach using semi-standardized expert interviews to investigate the overall case of brand worlds in B2B. This research method has previously proven purposeful in industrial marketing when there is scant or no existing information (e.g. Geiger, 2017; Keränen \& Jalkala, 2013), and has been deemed appropriate for research in exploratory stages (Bogner, Littig, \& Menz, 2009).

Since our goal was to gain a deeper understanding and orientation in the field of brand worlds, as well as to attain information exclusive to the experts, the interviews we conducted can be seen as a mixture of the 
exploratory and the systematizing variant of expert interviews (Bogner \& Menz, 2009). Although the interviews are qualitative and explorative in nature, prior theoretical knowledge about the concepts in the area of research is fundamental (Flick, 2009). This knowledge can then be used to develop interview guidelines, while the openly formulated questions leave room for the experts to fill with their specific knowledge (Mayer, 2012). Due to the lack of literature on brand worlds in B2B, we focused on the B2C literature and the value sources of brand worlds that are described there (e.g. Borghini et al., 2009; Diamond et al., 2009; Gilmore \& Pine, 2002; Hollenbeck et al., 2008; Joy et al., 2014; Kozinets et al., 2002; Sherry Jr et al., 2001; Sherry Jr., 1998). Based on this prior knowledge, we developed our interview guidelines, specifically targeting the motives of operating B2B companies, the expectations and values that visitors have and derive, the constituting elements and specifics, as well as the perception of the B2B brand worlds. Interview guidelines for all interviewee groups are provided in Appendices F-H.

\subsection{Sample}

To achieve a relevant and full understanding of brand worlds as an instrument of experiential marketing in business markets, we engaged with a comprehensive and unique, multi-perspective sample. Adding to the perspective of operating companies, we triangulated our findings with samples of business visitors and exhibition designers to achieve a $360^{\circ}$ view on the co-created B2B brand world experience, as depicted in Fig. $1{ }^{1}$ In total, we base our research on 37 expert interviews with 44 informants.

We carefully and thoroughly selected 17 companies operating B2B brand worlds, covering different industries and sizes from the US, Germany and Austria. We identified them through extensive online research and visiting practitioner conferences on experiential marketing and brand worlds. All participating companies operate different, outstanding, and innovative types of brand worlds - including for example Showrooms, Factory Tours, Visitor Centers, Customer Experience Centers, Museums, and Innovation Centers. One company was interviewed twice with different interviewees, because the firm operates two separate brand worlds in different locations with different goals. Where needed, we engaged both academic and private networks to establish a first contact with the selected companies via phone, and to introduce the research topic. We provided them with upfront information about the nature and the goal of the study via email. All informants were either directly managing the brand world or, if such a position did not exist, informants were closely related to the brand world and holding key informant positions such as Marketing Manager. Subsequently, we were invited to conduct 15 interviews on-site at the brand worlds and conducted three interviews by phone. In order to further ensure reliability and validity of our research, to put the interviews in context and enrich them, and to thoroughly get acquainted with all informants and components of the respective brand world, each on-site interview was preceded by an extensive tour throughout the entire brand world of roughly $1.5-2 \mathrm{~h}$. Due to the fact that the interviews were conducted directly after these extensive tours given to us by the respondents themselves, we could directly dive into the topic and start with the depth interview without the need to get acquainted during the beginning of the interviews. A detailed description of our sample of operating companies is provided in Table 5 .

To triangulate and enrich our findings from the company sample, and to answer our research questions regarding the expectations that business visitors have towards B2B brand worlds and the value they

\footnotetext{
${ }^{1}$ We thank both reviewers for their suggestion to gather additional data. Especially valuable was reviewer 2's comment, that value is only perceived by the user, not the designer. This led to the addition of the visitors' and the exhibition designers' perspective, which proved to be valuable sources of additional information, helping us to improve, triangulate and validate our findings.
}

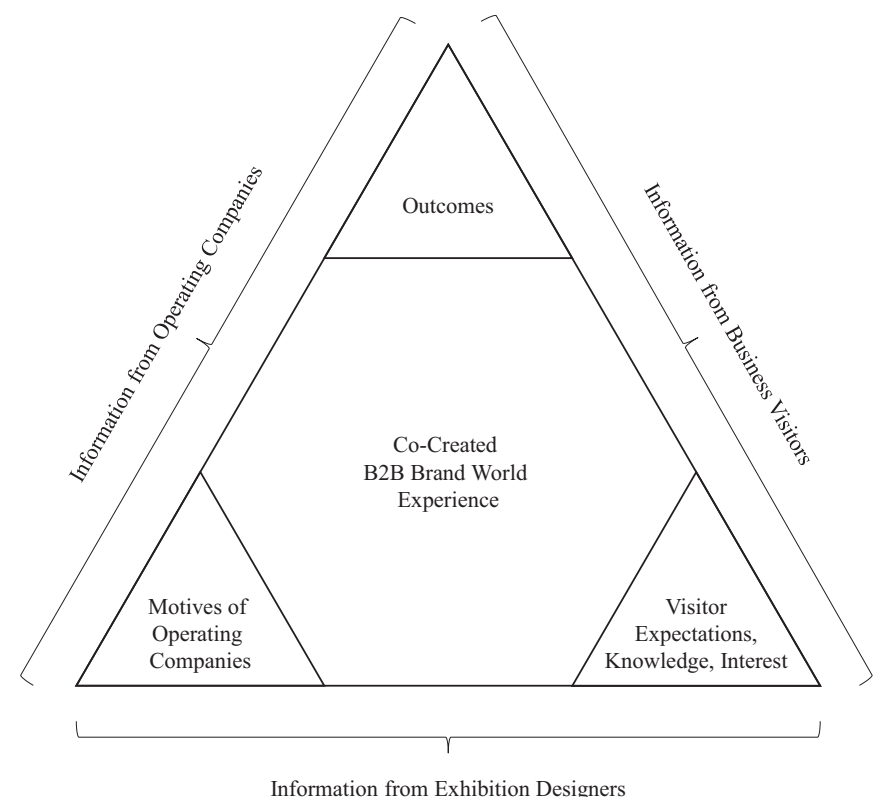

Fig. 1. A $360^{\circ}$ view on co-created B2B brand world experience.

derive from their B2B brand world experience, we also conducted 14 expert interviews with business visitors of B2B brand worlds. Informants are employed by 13 different companies in various industries and act in various buying center roles. They have visited at least one, some also several B2B brand worlds in a role as a business visitor recently before the interviews. To establish first contact, we engaged with them via the previously mentioned operating companies, or academic and private networks. 13 of the interviews were subsequently conducted via phone, one face-to-face. We provided informants with upfront information about the nature and the goal of the study, therefore we could directly start with the deep interview phase after giving another short introduction prior to the interview. A full, detailed description of our sample of business visitors is provided in Table 6 .

To additionally triangulate and validate our findings with a third, supplementary point of view, we conducted five more interviews with exhibition designers in managing positions at different exhibition design or marketing and brand agencies. This sample was chosen based on the extensive experience of the respective informants in designing and implementing various types of brand worlds for numerous companies in both the consumer and business marketing area. We established contact, introduced ourselves and informed the respondents about the research project upfront via email and phone. Subsequently, two interviews were conducted by phone, and three interviews were conducted at the informants' offices. A full overview of our sample of exhibition designers is provided in Table 7.

The overall average net duration of our interviews was $47 \mathrm{~min}$ of deep and relevant discussion. The overall average phone call duration was $53 \mathrm{~min}$. The overall average visit duration for on-site interviews at brand worlds or face-to-face interviews with visitors and exhibition designers was $2 \mathrm{~h}$ and $58 \mathrm{~min}$. We fully transcribed all interviews and presented them to the interviewees afterwards for validation. Where necessary, we translated the statements quoted in this study into English.

\subsection{Qualitative Content Analysis}

We analyzed the interview material using the method of qualitative content analysis, which is a systematic, rule-bound mixed-method approach (Mayring, 2014). Specifically, we used the technique of inductive category formation to arrive directly at summarizing categories coming from the material itself, and not from theoretical considerations 


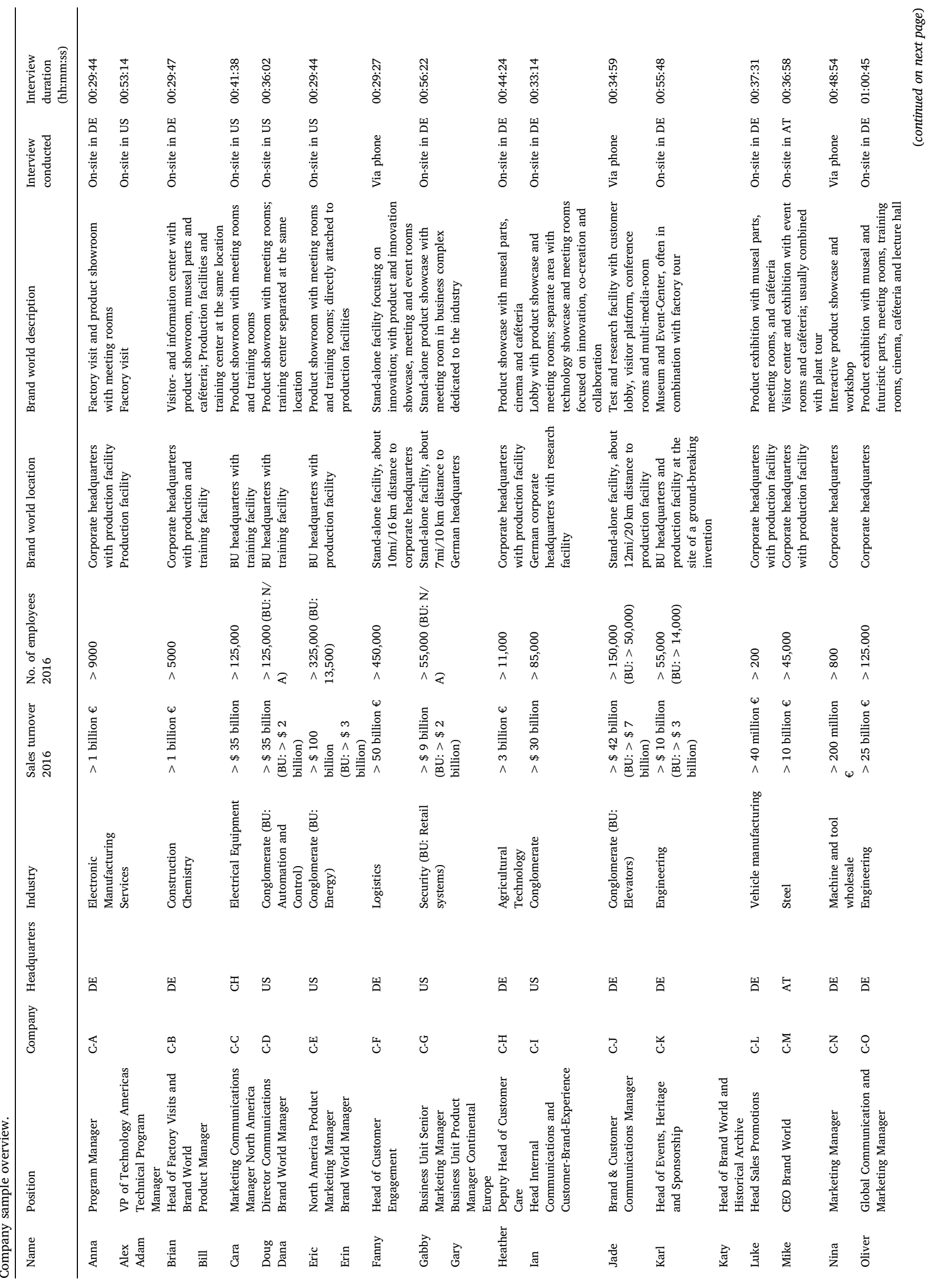



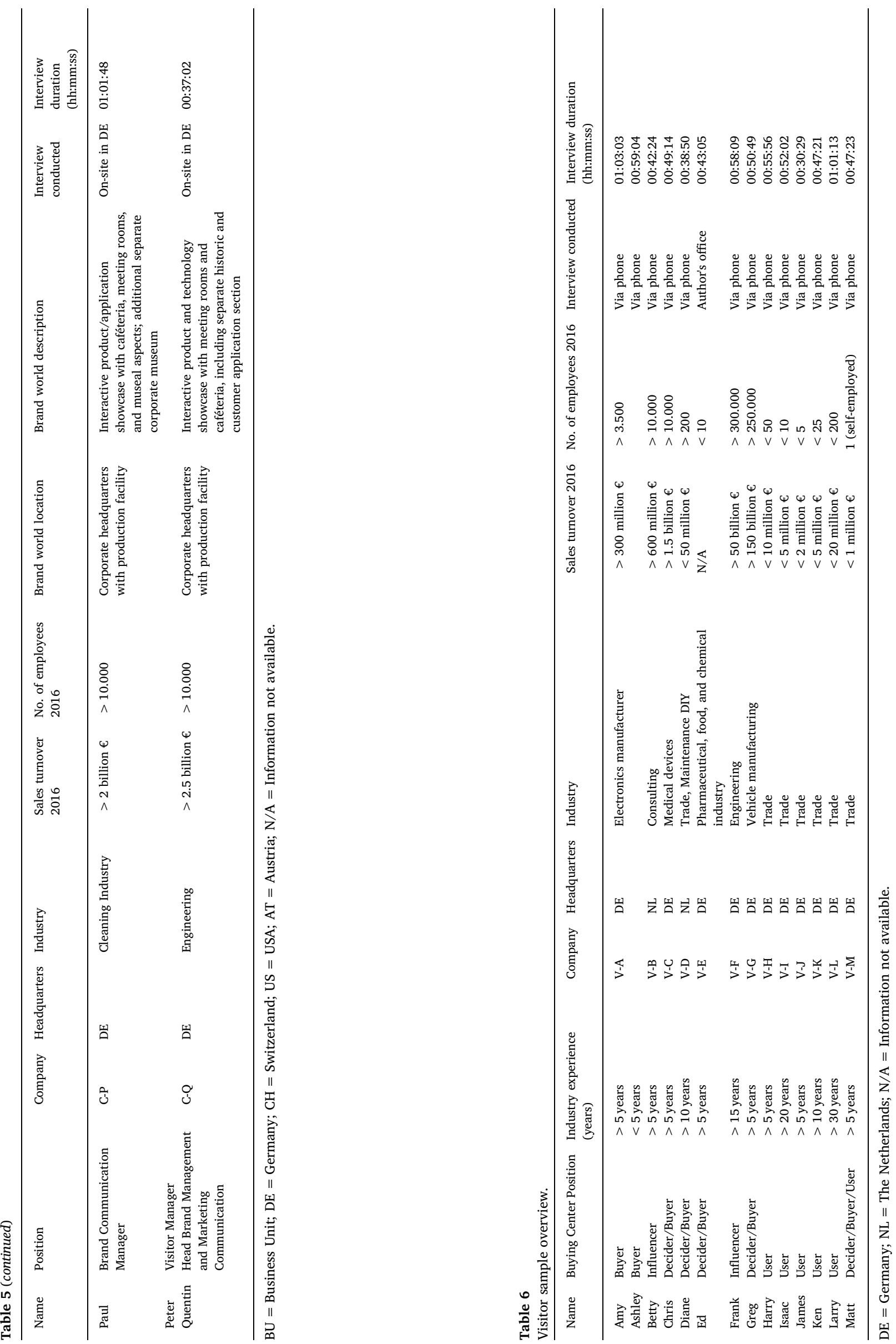
Table 7

Exhibition designer sample overview.

\begin{tabular}{|c|c|c|c|c|c|c|c|c|}
\hline Name & Position & Profession & $\begin{array}{l}\text { Industry } \\
\text { experience (years) }\end{array}$ & Company & Headquarters & $\begin{array}{l}\text { No. of employees } \\
2016\end{array}$ & $\begin{array}{l}\text { Interview } \\
\text { conducted }\end{array}$ & $\begin{array}{l}\text { Interview duration } \\
\text { (hh:mm:ss) }\end{array}$ \\
\hline Alan & $\begin{array}{l}\text { Partner, Head trade shows } \\
\text { and brand worlds }\end{array}$ & Interior designer & $>10$ years & D-A & $\mathrm{DE}$ & $>200$ & Via phone & 01:09:30 \\
\hline Bob & Associate & $\begin{array}{l}\text { Architect and industrial } \\
\text { designer }\end{array}$ & $>10$ years & D-B & $\mathrm{DE}$ & $>100$ & Informant's office & $01: 23: 48$ \\
\hline Craig & Creative Director & Communication designer & $>20$ years & D-C & $\mathrm{DE}$ & $>50$ & Informant's office & $00: 45: 22$ \\
\hline David & $\begin{array}{l}\text { Live Communication } \\
\text { Consultant }\end{array}$ & Communication designer & $>5$ years & D-D & $\mathrm{DE}$ & $>100$ & Informant's office & $00: 56: 48$ \\
\hline Earl & Managing Director & Exhibition designer & $>20$ years & D-E & $\mathrm{DE}$ & $>5$ & Via phone & $00: 31: 23$ \\
\hline
\end{tabular}

$\mathrm{DE}=$ Germany

(Mayring, 2014). This approach is similar to Grounded Theory, yet "more systematic" (Mayring, 2014, p. 79). The a priori definitions of what the relevant parts of the material are, as well the level of abstraction, are crucial to the analysis and are derived from the research questions (Mayring, 2014). Based on the aim of our qualitative approach, we included all material covering goals, expectations, value derived from the B2B brand world experience, the success factors, and differences between B2C and B2B brand worlds as relevant parts in the analysis. During the analysis process, we implemented several measures to ensure reliability and validity of our findings. We used a qualitative data management and analysis program (MaxQDA) and handled all interview transcripts with ultimate care. Two coders analyzed all data material separately, following established procedures developed for the inductive category formation technique of qualitative content analysis (Mayring, 2014). The process involves revising the emerging categories after approximately $50 \%$ of the content analysis, to arrive at a final category structure. We also investigated whether a revision of the initial coding definitions and instructions was necessary, but no issues arose during the coding process. We subsequently merged the codings based on thorough discussions between coders regarding the interpretation and categorization of individual informant statements, as well as a peer debriefing with other researchers not involved in the study (Gorley \& Gioia, 2004). Additionally, exemplary informants' statements demonstrate the plausibility of our results and are presented in the Appendices A-E.

\section{Results}

The goal of this study is threefold. First, to answer the question of why, to investigate the motives of industrial companies to implement a brand world, and to identify expectations B2B visitors have, and the value they derive from the experience of a B2B brand world visit; Second, to answer the question of what, to understand the nature of the B2B brand world and what it is constituted of; and third, to answer the question of how, to investigate how the B2B brand world is perceived and how the experience is co-created.

\subsection{Motives of companies operating B2B brand worlds}

With respect to why B2B companies operate brand worlds, our research revealed 18 different motives. Not all of them are relevant for each type of B2B brand world. We classified these motives based on the order of nomination by the informants, and the number of informants mentioning the specific goal. The most important goals that B2B companies pursue with their brand worlds are product awareness, brand associations, brand awareness, and product experiences.

Product awareness is the extent to which someone is aware of and familiar with a company's products and services, either through direct exposure or marketing efforts (Collins, 2007). Especially for organizations with a broad product portfolio, the brand worlds are an effective way to provide not only the visitor, but also own employees with a full overview and knowledge of the company's offering, and to showcase both already existing as well as new products.

Brand associations refer to three distinct perspectives on the brand (Aaker, 1996): brand-as-product (value), brand-as-person (personality), and brand-as-organization (organizational associations). The brand-asproduct perspective involves functional benefits and focuses on the value proposition of the brand; the brand-as-person perspective establishes a link to the brands emotional and self-expressive benefits, and is a basis for differentiation and customer relationships; the brand-as-organization perspective, also often an important differential factor, considers the organization and its people, values, and programs which lie behind the brand, and shows that a brand represents more than products and services. It includes "having a concern for customers, being innovative, striving for high quality, being successful, having visibility, being oriented toward the community, and being a global player" (Aaker, 1996, p. 113). All of these dimensions, but especially brand-as-person and brand-as-organization are important goals of B2B brand worlds, since B2B business involves a high level of personal interaction and trust in those individuals and their organizations. Brand worlds, in which dedicated one-on-one time is spent with the customer, from several hours up to sometimes several days in the case of trainings in the brand world, are a unique way to create those positive brand associations for the customer, and also strongly support internal and employer branding purposes.

Product experience refers to the vivid, personal use of products, to trying them out and experiencing their capabilities first-hand (Hoch, 2002). These live experiences of touching and trying the products in a B2B brand world directly convey their value-in-use, and additionally entail a sense of excitement, joy, play, and experiential learning for the visitor, be it an engineer, a purchaser or the user of the product.

Brand awareness is "the ability for a buyer to recognize or recall that a brand is a member of a certain product category" (Aaker, 1991, p. 61). It includes knowing what the brand stands for and having an opinion about the brand (Aaker, 1996). For several B2B companies this is a top goal they pursue with their brand worlds, closely linked to product awareness. Informants stated for example that most purchasers know the specific product category that they are buying quite well but sometimes not in full depth; that they are not aware of the full breadth of the offerings of the company; or that they link the company to only one specific product category that they might already be buying. Brand worlds serve as a means to widen and deepen the visitor's understanding of the company's offerings, and to create awareness for companies which are sometimes perceived as niche brands but are in fact global players.

Table 8 presents further motives that operating companies pursue with brand worlds, such as visitor's perceived quality/leadership of the brand, customer loyalty, the integration of the customer into business processes in the form of co-creation, initiating and enhancing customer relationships, initiating and closing sales, or internal and employer branding. They mostly build on the four aforementioned goals. For exemplary informant statements we refer to Appendix A. 
Table 8

Motives companies operating B2B brand worlds $(n=18)$.

\begin{tabular}{|c|c|c|c|c|c|}
\hline First nomination & \# & Second nomination & \# & Third nomination & \# \\
\hline Product Awareness & 8 & Brand Associations & 6 & $\begin{array}{l}\text { Initiate customer } \\
\text { relationship }\end{array}$ & 4 \\
\hline Brand Associations & 6 & Product Experience & 4 & Initiating sales & 3 \\
\hline Brand Awareness & 5 & $\begin{array}{l}\text { Perceived Quality/ } \\
\text { Leadership }\end{array}$ & 3 & Closing sales & 3 \\
\hline Product Experience & 4 & Product Awareness & 1 & Brand Associations & 2 \\
\hline Customer Integration & 1 & Customer Integration & 1 & Product Awareness & 2 \\
\hline Customer Loyalty & 1 & Customer Loyalty & 1 & $\begin{array}{l}\text { Perceived Quality/ } \\
\text { Leadership }\end{array}$ & 2 \\
\hline $\begin{array}{l}\text { Product Development } \\
\text { and Testing }\end{array}$ & 1 & $\begin{array}{l}\text { Enhance customer } \\
\text { relationship }\end{array}$ & 1 & $\begin{array}{l}\text { Employer/Internal } \\
\text { Branding }\end{array}$ & 2 \\
\hline \multirow[t]{6}{*}{ Transparency } & 1 & $\begin{array}{l}\text { Initiate customer } \\
\text { relationship }\end{array}$ & 1 & $\begin{array}{l}\text { Enhance customer } \\
\text { relationship }\end{array}$ & 2 \\
\hline & & Initiating sales & 1 & $\begin{array}{l}\text { Product } \\
\text { Experience }\end{array}$ & 1 \\
\hline & & $\begin{array}{l}\text { Employer/Internal } \\
\text { Branding }\end{array}$ & 1 & $\begin{array}{l}\text { Customer } \\
\text { Integration }\end{array}$ & 1 \\
\hline & & $\begin{array}{l}\text { Proving marketing } \\
\text { claims }\end{array}$ & 1 & Brand Awareness & 1 \\
\hline & & Differentiation & 1 & & \\
\hline & & $\begin{array}{l}\text { Provide a branded } \\
\text { experience }\end{array}$ & 1 & & \\
\hline
\end{tabular}

\subsection{Expectations of business visitors of $B 2 B$ brand worlds}

The expectations of business visitors regarding their visit to a B2B brand world, i.e. the reasons why prior to the visit, focus on the generation of knowledge, related to the products and the operating company itself. Visitors expect to learn something new or understand something that they would not be able to understand or learn without the brand world visit, and they largely expect that this curiosity and thirst for knowledge are satisfied in a pleasant and appealing atmosphere.

This means that business visitors for example want to get to know the whole range of products and services the operating company has to offer, try the products themselves or see the products in use. Visitors also expect to see the product in a larger context, if possible, e.g. some application examples of where and how the product can be used, or to be shown how an industrial product relates to their day-to-day private life. Additionally, visitors want to be able to easily and quickly understand the technical functions and added value of complex products and services, and get some background information on the products, such as where and how they are produced, or what materials are used.

Visitors also want to get to know better the operating company, based on information such as current facts and figures on employee numbers, turnover, target markets, and main pillars and competencies of the company. Additionally, information on the history of the company as well as an outlook on the future development are expected, as well as references such as other major customers. Visitors also expected to get to know the corporate culture and expected to see, whether what is shown during the brand world visit matches their daily experiences in their business relationship with the operating company.

Interestingly, several business visitors also expected an emotionally appealing or even entertaining character of the brand world visit, even in the B2B context, in a way that positive emotions such as excitement or even fun are elicited. Additionally, in general business visitors expect to feel valued by the operating company and to have a sense of wellbeing during their visit. For a full list of categories of business visitors' expectations and exemplary informant statements, we refer to Appendix B.

\subsection{Value of the experiences at $B 2 B$ brand worlds for $B 2 B$ visitors}

Based on our analysis, we found several types of value that business visitors derive from their $\mathrm{B} 2 \mathrm{~B}$ brand world visits, i.e. answers to the question of why they go to B2B brand worlds subsequent to their visit. Our research shows that several specifics emerge in comparison to the value types created in B2B networking events as outlined in section 2.3 of this paper. At the same time, it shows that, bearing in mind these specifics, those general value types can be transferred to the related experiential marketing area. An overview of informants' statements supporting our findings, exemplary sub-ordinate value dimensions, and all superordinate value dimensions is given in Appendix C.

Little surprisingly, the learning, epistemic and knowledge value of the B2B brand world experience plays the most important role for the respondents, alongside the closely related professional value they derive for their daily business activities from this knowledge or information. Basically, the visit to a brand world should not primarily be autotelic, meaning an end in itself, but instead value is derived from the brand world experience if it helps the visitors in their jobs. This includes gathering and generating new knowledge and information for the visitor; getting information about the company, its history, origin and vision; theoretical information about a company's products and offerings; application examples that make it possible for the visitor to grasp the functions and benefits of a complex or abstract product quickly; and also practical product trainings for users are sources of value, that are instrumental and functional in nature, and support the visitor in his daily business. In short, visitors derive value if the visits serve their business goals.

A very interesting finding though is, that business visitors also derive value from the more emotional aspects of the brand world experience. If the visit entails a sense of edutainment or infotainment, or the exhibits are linked to everyday life, this also makes it easier and more engaging for the visitor to understand otherwise complex or abstract products or services. These senses of enthusiasm, fascination for and emotional bond with products derived from these emotional encounters make it also easier for visitors to remember the features and benefits of products and services, and thus support or maybe even influence the decision-making process. Additionally, in a form of escapism, one respondent who is in the role of the user of B2B products, states that it is also sometimes simply nice and enjoyable to get out of the daily business and see something different and new.

Furthermore, visitors derive value from the relational dimension of the experience. Based on the time spent together in the brand world, the information about the company, its heritage, and competence, and the quality and benefits of its products that are presented there, the visit enables them to establish or strengthen a relationship and trust with the organization as a whole, but equally important with their contact persons and other individuals within that organization.

Interestingly, the hedonic, altruistic, entertainment, service excellence value dimension, which targets the experience as an end in itself, also played a role for several business visitors of B2B brand worlds. For example, visitors derive value and a form of pleasure and fascination from the appreciation of well designed and engineered products which are on exhibition, either as a whole or as cutaway models, which allow for a more detailed examination of the way a product works. Additionally, 'wow effects' can be created by architectural or design elements which might be linked to the heritage or the products of a company, or simply by the first-hand experience created by the use of the products, or also by getting to know the overall heritage of industrial companies. At the same time though, respondents also state that they did not perceive the brand world as a kind of tourist attraction in the sense of some B2C brand worlds and made the humoristic overstatement that they would not have made the way to the B2B brand world to spent some time there in private on a Saturday.

The innovation value business visitors derive from a brand world visit is based on the presentation of new products and also the full breadth and depth of products. Several respondents stated that in the brand world they saw products that they were not aware of, and which would help either them directly or also colleagues or their whole organization in their business endeavors. 
The reputation, status, esteem, branding value dimension only played a minor role, with two respondents stating that the knowledge and product awareness generated in the brand world and the relationship with the operating company would help them to further differentiate themselves from their own competitors.

Similarly, social value was only mentioned by two respondents stating that they told their friends and family about the visit. A sense of community or enjoyment of the visit together with peers, as is the case for B2C brand worlds, was not mentioned by our respondents.

\subsection{The nature of the $B 2 B$ brand world}

\subsubsection{B2B brand world contents}

Our respondents have stated in various ways, that the development of a brand world begins with what is supposed to be conveyed there: the content of the B2B brand world. This content, which is based on information, stories, images, and other resources, has to be first investigated and then defined in detail, and should then transform into a common, golden thread leading through the brand world. It is influenced both by the motives of operating companies, as well as the expectations, knowledge, skills, and interests of the visitor. Very much in contrast to B2C brand worlds, where consumers are driven by and expect hedonic aspects, and where visits take place fully unrelated to specific purchase intentions and are based completely on the own intention to visit, business visitors to B2B brand worlds are motivated by and expect more utilitarian aspects. Their visits are usually related to specific purchasing intentions or an already existing customer-brand relationship, in the process of which they are invited by the operating company to a company visit. In fact, they often do not visit the company to 'visit the brand world', but to conduct their general business activities, such as meetings, workshops, negotiations, audits, relationship maintenance, or trainings. The B2B brand world is then rather used by the operating company as a three-dimensional 'business card', a tool where the company presents itself at a glance, or as a complementary instrument to provide the visitor with either an additional experience to present a positive, credible image, or as an extraordinary and stimulating location in which, by the provision of additional, unique information, mutual value is created and where these business activities take place. Yet, since the aforementioned expectations vary from individual to individual, the content of the visit should be highly contextual and individualized, and the focus of the entire visit should not be on presenting the company or the brand, but on the visitor, his needs, and the company's ability to satisfy those needs. Thus, the brand world visit and its content have to be easily modifiable for the demands and needs of several target groups, be them customers and their purchasing agents or product users, marketing or sales agents, top level managers, own employees or potential employees, or media and press or governmental institutions. Accordingly, high flexibility is needed to cater to the needs of the visitor, which are based on the social situatedness of the individual visitor or his organization, e.g. whether a prior relationship to the brand or the individual employee or guide of the operating company exists.

Bearing in mind this different contextual setting for the B2B brand world, several common themes have been mentioned by our respondents as content that should be conveyed in order to provide a successful B2B brand world visit for all actors involved. First of all, the brand world and its content provide the possibility to experience the brand, its core and values "in-vivo" by making it tangible. Therefore, at the heart of the visit are the themes that define the brand, that make it special, and that also differentiate it from its competitors. By displaying the competency and ability of the brand and its products throughout history, present, and future on the one hand, and by offering an authentic, honest, consistent, and transparent view on the brand on the other hand, a certain level of trust in the operating company can be established. Furthermore, what is part of the golden thread leading through B2B brand worlds, is the notion of positioning the brand as the right partner for the visitor, by displaying that one understands the visitors needs and problems and is also able to solve them. Furthermore, in order to fulfill the visitor's need for the visit to support him in his business activities, the content should be woven into an educational process, in which the deep, detailed, and precise explanation of technically complex products, for example by means of exemplary use cases, or in other easy and even ludic ways, play an important role. An important part of this process is also to relate the brand and its product, which might be very abstract, to the visitor's daily life, to facilitate his understanding of and identification with the brand and its products. The education about the whole breadth and depth of the company's offering is also content useful for the visitor. The brand world visit should additionally provide information which is unique and goes beyond the content of the brands webpage. Furthermore, an important part of the content of the brand world, given its more influential role in B2B and more complex products and services, is the personal interaction with employees of the operating company, through which the brand can actually be given a face. In its own brand world, the operating company and its employees have the chance to spend focused, face-to-face time with the business visitor. Therefore, B2B brand worlds are guided experiences, so that visitors are always accompanied by a contact person representing the brand, elaborating on the exhibits, and building a relationship with the visitor. This goes along with a much more customized visit, in which the specific areas of interest of the business visitor are discussed in much more detail and depth. At the heart of this personalized visit is also to make the visitor feel special, appreciated, and esteemed by the operating company. Furthermore, although in a B2B context, respondents also stated that the content of the brand world should emotionalize, fascinate, and immerse the visitor - less with a hedonic goal, but more in order to support remembrance, and to evoke more serious kinds of emotions, such as trust, credibility, authenticity and reassurance. Nevertheless, also edutaining contents play an increasing role according to our respondents. Supportive informant statements on the B2B brand world content can be found in Appendix D.

\subsection{2. $B 2 B$ brand world experiencescape}

The contents of the B2B brand world manifest in the B2B brand world experiencescape. Experiencescapes are "the spaces in which experiences are staged and consumed [that] can be likened to stylized landscapes that are strategically planned, laid out, and designed. They are, in this sense, landscapes of experience" (O'Dell, 2010, p. 16). This experiencescape comprises physical artifacts and spaces on the one hand, and the social environment and practices on the other. Both contribute to convey the contents outlined above and are the answer to the question of what the B2B brand world consists of.

Respondents state that, in order for the artifacts and spaces which constitute the brand world physically to convey the content, they are tangible embodiments of the brand itself. The way the content is presented has to fit the brand and its spirit to provide the visitor with an authentic, and consistent image. Furthermore, the artifacts and spaces have to create an emotionally appealing, intriguing, also surprising and immersive atmosphere, and they do this by experiential techniques which appeal to all the visitor's senses of sight, hearing, taste, smell, and touch within the brand world space. Overall, respondents stated that the physical B2B brand world space is and should be contemporary, upto-date, and clean, as all physical aspects reflect on the brand operating the premises. Given the professional background of B2B visitors, the artifacts and spaces are, compared to their B2C counterparts, also characterized by a generally less exhaustive orchestration, staging and hyperbolism, following the conviction of "less is more", and instead focusing on the relevancy for the visitor, the ease of use and the raisons d'être of each exhibit. This physical embodiment of the brand and its spirit in the B2B brand world experiencescape culminates in what one respondent called the "genius loci", which is both related to the physical location of the B2B brand world, and the designed artifacts and 
spaces. Regarding the location, the B2B brand worlds are, also in contrast to many of their B2C counterparts such as showrooms and flagship stores, mainly situated either at locations linked to the heritage of the brand, as the founding site or the site of important inventions, or at the corporate headquarters. Both locations already imply a special feeling of visiting the origins or the roots of the brand, and as such contribute to the overall experience. Regarding the designed artifacts and spaces, these are often not only mere functional instruments to convey the content but are designed in such a way that make linkages to the brand's core, heritage, products, or the production facilities, and thus they also contribute strongly to the overall experience within the brand world.

Regarding social environment and practices, these also represent the brand, and are designed to a certain extent by the operating company in form of behavioral branding, and the corresponding behavior of employees towards the visitors. In general, the brand world and its contents have to be 'lived' by the employees, and respondents stated that, at first glance quite generic or obvious behaviors and aspects, such as competence, friendliness, passion, professionality and again the focus on the visitor and his needs by the brand world's employees or guides are important for delivering a consistent picture. But given the more influential role of personal interaction and more complex products and services in B2B, this explicit expression of the importance of the social environment makes sense. This also leads to B2B brand worlds being mostly guided experiences, so that visitors are always accompanied by either their specific contact person within the company, representing the brand, elaborating on the exhibits, and building a relationship with the visitor, and/or a specific guide for the brand world. This goes along with a much more customized visit, in which the specific areas of interest of the business visitor are discussed in much more detail and depth. Additionally, for visitors it is an important aspect to not only get to know their sales person better, but also to personally meet with and getting to know other employees such as for example product managers, sales managers, or service or internal sales support employees, that they normally only communicate with via email or phone. Supportive informant statements on the B2B brand world experiencescape can be found in Appendix E.

\section{Discussion and conclusion}

\subsection{Understanding the nature of $B 2 B$ brand worlds and how they are experienced}

Brand worlds as the apex of branding, which use experiential marketing techniques, have made their way from the consumer area into business marketing practice. Given the different B2B context (Brown et al., 2007), the direct transfer of theories, frameworks, and knowledge from B2C to B2B should be approached with caution. In order to understand the nature and phenomenon of brand worlds in the B2B context and how they are experienced, we conducted exploratory empirical research with the goal to get a comprehensive view on brand worlds, and interviewed operating companies, exhibition designers, and business visitors. We now synthesize and interpret our findings and summarize our comprehensive view on B2B brand worlds in Fig. 2 .

In $\mathrm{B} 2 \mathrm{C}$, when visiting a brand world, consumers are driven by and expect hedonic aspects. Consumer visits take place fully unrelated to specific purchase intentions and are based completely on consumer's own intention to visit. In contrary, business visitors to B2B brand worlds are motivated by and expect more utilitarian aspects. Their visits are usually related to specific purchasing intentions, initial business contacts, or an already existing customer-brand relationship, in the process of which they are invited by the operating company to a company visit. In fact, they often do not visit the company to 'visit the brand world', but to conduct their general business activities, such as meetings, workshops, negotiations, audits, relationship maintenance, or trainings. Looking at the what, namely what the B2B brand worlds consists of, its contents and the experiencescape, and further to its nature and what its purpose is in $\mathrm{B} 2 \mathrm{~B}$, our research shows that against this professional background, it is used by the operating company as a 'business card', a tool where the company presents itself, its core, values, identity and products at a glance for the visitor to experience. It is a complementary instrument to provide the visitor with either an additional experience to present a positive, credible image, or as an extraordinary and stimulating location in which, by the provision of additional, unique information and the possibility to experience the brand, its products and employees 'in-vivo', mutual value in the form of learning, epistemic, and knowledge, relationship, or professional value is created. Based on these relevant experiences they provide for the visitor, B2B brand worlds are the ideal locus for or complementation to such business activities related to specific purchasing intentions, initial business contacts, or the deepening of an already existing business relationship. Looking at the why, our respondents stated that for conveying the brand's identity and portfolio in all its breadth and depth, and for the visitor to getting to know the operating company in this breadth and depth, the instrument of brand worlds is superior to any other marketing instrument based on the direct experience it provides:

"For the breadth that [the brand] has, this is a very quick way to see just how much our company can do, is capable of, how diverse our portfolio is. [...] I think [...] that this space gives that picture more effectively than anything I can think of off the top of my head." (Cara, operating company)

Reflecting on Carù and Cova's (2007) continuum of experiences ranging from constructed by the consumer, through co-created by consumer and organization, to largely constructed by the organization the experience at B2B brand worlds can clearly be described as cocreated by both the organization and the visitor. Looking at the underlying mechanism of how these experiences are co-created, two things are at the core of the B2B brand world experience itself: the brand world experiencescape, reflecting the company's contribution to the cocreated B2B brand world experience; and the embodied cognition of the B2B brand world, reflecting the visitor's contribution to how he experiences the B2B brand world. The experiencescape and its physical artifacts and spaces and social environments and practices are manifestations of the motives that the operating company wants to achieve with the content they provide to their visitors in their brand world. The success of brand worlds in general is based on the fact that these experiencescapes are largely controlled by the manufacturer itself, where the operating company can holistically and vividly present its brand (Kozinets et al., 2002). However, respondents stated that if they do not deem the information and content provided during the visit as relevant and useful for them, then this decreases their perceived experience in the brand world. A key finding of our research therefore is, that in order to address the varieties of different buying center members and to explain complex products, the visits have to be tailored to the specific expectations, levels of knowledge, skills, and interests of each individual visitor. On the other hand, if the brand world visit is relevant and useful for the visitor, and if it thus supports the visitor in his business activities, this leads to an enhanced brand world experience. Therefore, the operating companies tailor the content of the experience either a priori or ad-hoc during the visit, with the help of guides and interactive, multifunctional exhibits and spaces, to the specific needs of the visitors, and largely focus on those products and information, that the visitor is really interested in. Therefore, one can say that not only the motives of the operating company, but also the expectations, knowledge, skills, and interests of the visitor influence the content of the $\mathrm{B} 2 \mathrm{~B}$ brand world visit, and it is at this point of the co-creation of the B2B brand world experience, where a first alignment between motives of the operating company and the expectations of the visitor takes place. The content then becomes manifest in the core of the B2B brand world, the experiencescape, comprising the designed artifacts and spaces, which constitute the physical premises of the B2B brand world, as well as the social environment and practices of employees and their behaviors at the B2B brand world. 
Company sphere and contribution

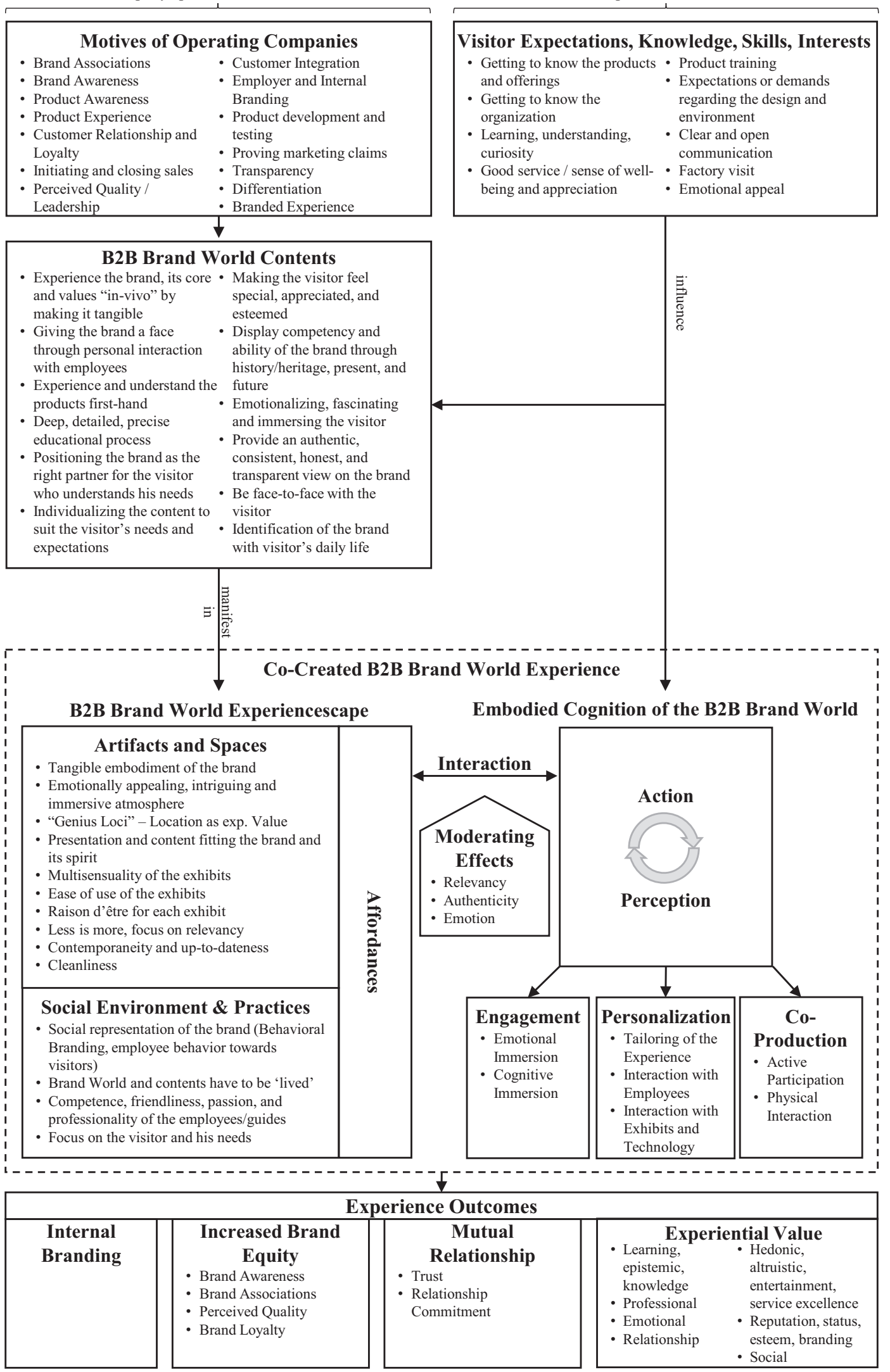

Fig. 2. A comprehensive view on B2B brand worlds. 
The involvement, immersion and interaction of the consumer with his physical environment is a part of the co-creation of extraordinary experiences (Kozinets et al., 2004). Furthermore, branding in business markets essentially is a form of communicative interaction (Ballantyne \& Aitken, 2007); especially the deep, personal interactions between employees, customers, and stakeholders evoke the co-creation of branded experiences, and are a key factor for establishing business relationships. From a phenomenological perspective, both the artifacts and spaces as well as the social environment and practices of the B2B brand world experiencescape provide affordances for the embodied visitor to act upon and perceive, based on the application of a multitude of experiential marketing techniques which focuses on various senses. How the individual visitor does act upon and perceive these affordances is again influenced by his expectations, level of knowledge, skills, and interests. A key finding of our research is, that through his action and perception on these affordances, the visitor in turn interacts with and influences both these physical artifacts and spaces, as well as the social environment. This thus leads to a joint action-perception cycle, through which the experience of the visitor at the B2B brand world is co-created between the visitor himself and the B2B brand world experiencescape. Therefore, a second alignment between the operating company's motives, as expressed in the content provided through the experiencescape, and the visitor's expectations takes place in this joint actionperception cycle and interaction between visitor and experiencescape. This interaction and relationship-building with subjects (i.e. the brands employees), as well as the interaction with, perception with all senses of, and immersion in the environment leads to further engagement, a personalization and co-production of the B2B brand world experience and facilitates learning and relationship-building in the brand world. In essence, it is how the B2B brand world experience itself, and the value in it for both parties, is co-created.

Further key findings of our research are that the factors relevancy, authenticity, and emotion directly influence this interaction between experiencescape and visitor, and as such the entire co-creation of the B2B brand world experience. As described before, the visitor has to get a functional and instrumental benefit from the brand world experience, which helps him in his business activities. Therefore, the content of the visit should be highly contextual and individualized, and the brand world has to be easily modifiable for the demands and needs of several target groups, be them customers and their purchasing agents or product users, marketing or sales agents, top level managers, own employees or potential employees, or media and press or governmental institutions. As a consequence, also all the exhibits have to serve a deeper purpose of information or education and should not be an end in themselves. The more authentically, open, and honest the brand's characteristics and identity are presented, and the more consistent this presentation in the brand world is with other brand communication instruments, and the visitor's experience with the brand in daily business, the more intense and credible is the brand experience for the visitor. If the picture that is drawn of the brand in the brand world is not authentic, inconsistent with visitors' prior experiences with the brand and its employees in their daily lives, or if information provided seems unrealistic, then the visitors feel deceived. Both relevancy and authenticity are cognitive perceptions and evaluations of what the company contributes to the co-creation of the experience, namely the content as manifested in the B2B brand world experiencescape. This evaluation is situated in the visitor. It is only possible through interaction with the experiencescape, and also influences this interaction and thus the co-creation of the entire B2B brand world experience, and the value the experience has for the visitor. If the brand world experience is not perceived as being relevant to the business visitor he derives less or even no value from it, and the visit is useless to him. Regarding this value, respondents describe brand worlds as even more effective as trade shows in presenting an overview of the full product range on offer and getting to know the brand. Providing the visitors with a real, lived experience with the brand and its products is crucial for B2B brand worlds. The interesting and exciting experiences, encounters, interactions, and activities that $\mathrm{B} 2 \mathrm{~B}$ brands provide in these locations - not only to externals but also to employees - simplify understanding, learning, and remembrance for the visitor. Similarly, if the overall experience in the brand world is not perceived as being authentic or trustworthy, it diminishes the value derived from the experience for the visitor.

In contrast to relevancy and authenticity, emotions are not a cognitive evaluation, but affective responses to external stimuli such as adaptive problems (Ekman, 1992; Plutchik, 1980). Thus, they are not an evaluation of the company's offering in the brand world, such as perceived relevance or authenticity, but affective responses to both the co-creation composites of the company and the visitor. Since emotion and experience are two closely related concepts, emotion is a key factor for a positive experience also in B2B brand worlds. This emotionality is less strongly pronounced compared to B2C brand worlds, but still an important aspect. These emotions entail for example a general emotional appeal, a sense of well-being and appreciation of the visitor by the operating company, communication on eye-level, but also woweffects and fascination, for example in combination with architecture and design which have to represent the brand. Such emotional aspects do play an important role as a factor influencing the interaction between experiencescape and visitor, even in the business context. Engineers or technically interested visitors do react emotional, with joy or a sense of entertainment and enthusiasm, if they have the possibility to interact and get involved with the environment in the brand world, if they can try out, play with, and experience products. These emotions in turn lead to a more positive experience of the brand world. Also, the perception of impressive architecture or the interaction with employees can lead to positive emotional responses. Similarly, if employees behave in an unpleasant or unprofessional way, the premises do not meet the visitor's expectations regarding cleanliness, or the content provided is not immersive or irrelevant to the visitor, this results in a more negative experience. Furthermore, positive emotions that are evoked during the visit of the B2B brand world experience facilitate and support visitors' understanding and remembrance of the information and content provided in the brand world, their decision making, and also relationship building with the brand and its employees.

In the context of business networking events, eight main experiential value dimensions have been identified (Mitchell et al., 2016), all of which are supported by our study of the B2B brand world experience. With regard to the learning, epistemic, and knowledge dimension, learning is defined by experiential learning theorists as "the process whereby knowledge is created through the transformation of experience. Knowledge results from the combination of grasping and transforming experience" (Kolb, 1984, p. 41). The findings of our study show that with providing interactive product experiences in brand worlds, operating companies want to enable this transfer of knowledge. The products and their functions can be touched, tested and examined, and sometimes the production process is presented in a factory tour. These direct, hands-on, personal experiences that can be created with experiential marketing activities such as brand worlds will leave a deeper impression on the visitor's mind, and create more knowledge than regular information materials, advertising instruments, or trade magazines. Additionally, they let the visitors directly experience the products' or services' value-in-use. The operating companies openly present their value propositions, and provide the visitors with the opportunity to directly assess these propositions interactively (Lindgreen, 2012; Woodruff, 1997). Further values derived from the experience are professional value, relationship value, emotional value, hedonic, altruistic, entertainment, and service excellence value, reputation, status, esteem, and branding value, as well as social value. Based on respondents' statements, we have also reason to hypothesize, that further outcomes of the B2B brand world experience comprise an improve in relationship outcomes, such as mutual trust and relationship commitment, an increase or positive influence on brand equity and its dimensions brand 
awareness, brand associations, perceived quality, and brand loyalty, as well as a positive influence on the internal branding purposes of the operating company.

\subsection{Theoretical implications}

To the best of our knowledge, our exploratory study is the first to investigate brand worlds as an instrument of branding, employing experiential marketing techniques, in the B2B context. The study answers a general call for further research on experiential marketing activities in business markets (Rinallo et al., 2010) and contributes to the literature on the branding instrument of brand worlds specifically. By investigating it from multiple perspectives, namely the operating companies', the business visitors', and the exhibition designers', it expands the literature from merely describing its existence in B2B (Gilmore \& Pine, 2002) to a comprehensive and holistic understanding of its nature, as well as the why, what, and how of this phenomenon. Our study thus contributes to the understanding of the industrial marketing equivalent of one of the most powerful branding instruments in consumer markets (Dolbec \& Chebat, 2013). It introduces B2B brand worlds as a valuable alternative and complementation to existing B2B branding instruments for the operating company, but also as a valuable tool for the business visitor, based on the experience that is co-created there. Therefore, our study also contributes to the frameworks of the tactics of brand building and brand management, as well as the customer experience in business markets (Lindgreen, Beverland, \& Farrelly, 2010; Mora Cortez \& Johnston, 2017). An interesting area of future research arises in the investigation of the specific role of B2B brand worlds in the entire customer journey and relationship between businesses. Our findings show that the operating companies especially value the brand worlds as materialized business cards and figurehead of their brand. If one of the actors involved possesses a brand world, they often provide the inspiring and stimulating physical environment for a first personal meeting and interaction, and thus the foundation for a future relationship between the operating company and other actors on business markets. These relationships and interactions between actors are core aspects of business markets (Håkansson, 1982; Håkansson \& Snehota, 1995). Based on environmental psychology literature, we expect the brand world's stimuli, atmospherics and servicescape to influence how these relationships and interactions are perceived (Bitner, 1992; Kotler, 1973; Mehrabian \& Russell, 1974). Therefore, a quantitative investigation into the impact of a brand world visit on the visitor's perception of the brand seems fruitful. Furthermore, quantitative investigations of our propositions pose interesting avenues for future research, for example in order to investigate the impact of the specific success factors on the overall experience and the value subsequently derived from the brand world visit.

Research on value in business markets highlights that the delivery of value requires loyalty and trust between partners (Lindgreen, Hingley, Grant, \& Morgan, 2012), which both are core goals that B2B brands pursue with their brand worlds. The dimensions of value that business visitors derive from the experience of visiting a B2B brand world also show a substantial overlap with experiential dimensions in the B2C context, as described for example by Gentile et al. (2007) or Lemon and Verhoef (2016). Recent research concerning perceived value in B2B especially highlights the possible advantages of a cross-fertilization of value research in both B2C and B2B in order to fill research gaps of the respectively other field. The authors specifically propose the inclusion of more non-rational dimensions in the appreciation of perceived value in B2B (Mencarelli \& Rivière, 2015). These include feelings, atmosphere, or positive emotions, which are relevant in long-lasting customer relationships (Andersen \& Kumar, 2006). Our study shows that values derived from experiences in business encounters, such as the visit of a B2B brand world, also comprises these emotional and hedonic aspects and thus contributes to the literature stream on value in business markets. Future research might engage in the investigation of experiential value derived from other experiences in business markets, both qualitatively and quantitively. Our research shows that by providing interactive product experiences in the brand worlds, where the products and their functions can be touched, tested and examined, and sometimes also the production process of the products is presented, visitors are able to directly experience the products' or services' value propositions and value-in-use (Lindgreen, 2012; Woodruff, 1997). Based on the literature on product experience in the consumer area (Hoch, 2002), an interesting question for future research that emerges from this direct product experience is whether it influences purchasing intentions or even purchasing behavior.

The role of emotions in $\mathrm{B} 2 \mathrm{~B}$ markets has recently also gained increased attention from academia (Borders \& Kemp, 2018). Emotions play a role at all stages in the organizational buying process. Therefore, individuals, as opposed to entire organizations, should play a role in a B2B brand's marketing communications (Kemp et al., 2018). We contribute to this stream of literature by identifying that not only do visitors derive emotional value from the B2B brand world experience, but in fact, the emotions evoked in the context the experience of B2B brand worlds, which is highly individualized due to the close personal interaction with the brand's employees on the brand world premises, facilitate and enhance learning, remembering, and relationship-building. Emotions thus play a crucial role in the co-creation of the B2B brand world experience, and the overall value and success of $\mathrm{B} 2 \mathrm{~B}$ brand worlds, both for the operating company as well as for the visitor. We especially deem it necessary to further investigate the role of emotions between a brand's marketing communication instruments and the outcomes of these marketing efforts on business markets.

\subsection{Managerial implications}

Our research has important implications for business marketing practice. In light of increasing globalization and commoditization, branding nowadays plays an important role on industrial markets. Our findings indicate that if a brand world is implemented by a B2B company, it can become its flagship, its business card, and figurehead, much as it is the case in B2C. It is the materialization of the brand and invites not only customers, but also employees and a myriad of other stakeholders to visit and to getting to know the brand. By focusing on the more utilitarian aspects of the experience - and with the support of hedonic ones - the operating companies can set up the brand worlds to create a meaningful, valuable experience for their business visitors, which can leave a long-lasting positive impression and help building and maintaining a strong brand. Bearing in mind the differentiation between more autotelic experiences in $\mathrm{B} 2 \mathrm{C}$ and more instrumental experiences in $\mathrm{B} 2 \mathrm{~B}$, brand worlds can provide not only a suitable, but an extraordinary frame for business meetings, trainings, and events with (potential) customers or other stakeholders.

Regarding brand communication, brand worlds provide an environment fully controlled by the operating company. With themed experiences, where physical cues such as symbols, signals or stories are used to inspire the senses, the brand's core and values can effectively be conveyed to the visitor with almost no distorting external influences. If a company aims at increasing product awareness, brand worlds are for example more effective than trade shows in giving a quick yet full overview of the brands' offerings. Additionally, brand worlds in B2B are also educational tools, enhancing learning on products, processes, or the brand itself in interactive, experiential situations where visitors can for example have a live, direct, and hands-on try with the product. All these functions of the brand world eventually aim to contribute to an overarching company goal, by strengthening the brand's image, position in the market, collaboration, relationships, and interaction with other business market actors.

Our study identified not only the possible benefits of a brand word in business markets, but also how the experience is co-created. Since sometimes only minimal investments are necessary to turn factories 
into small-scale brand worlds, it can be a worthwhile undertaking (Kozinets et al., 2002). A museum attached to a factory, or museal aspects in a B2B brand world for example will help to demonstrate the history and experience of the brand in a certain field, which results in reduced uncertainty on the customer side and a more positive brand perception. Furthermore, interactive exhibits and information displayed in an engaging, immersive, and involving way facilitate understanding and learning for the visitor. Therefore, we encourage B2B branding practitioners to take advantage of these strong brand experiences evoked in brand worlds and consider them as an additional instrument in their tactics of brand building and brand management.

\subsection{Limitations and outlook}

Our study focuses on eliciting qualitative information. While it succeeds in answering questions on what the drivers of industrial brand worlds are and which consequences can be anticipated, the actual strength of effects still remains to be determined by means of quantitative studies. Another quantitative question of utmost managerial importance is of financial nature: How much budget should a firm allocate to industrial brand worlds? In order to facilitate well-informed decisions, future research should try to quantify the return on investment yielded by industrial brand worlds. Optimally, this would lead to an indication of 'brand world elasticity', which would allow B2B marketers to design and manage industrial brand worlds much like price, advertisement, and professional selling, for which elasticities are an established decision tool (Albers, Mantrala, \& Sridhar, 2010).

To conclude, our research shows that B2B brand worlds, based on the experiential techniques they employ, are valuable instruments for branding and relationship-building. Companies can actually present their brand and its products and services 'in the flesh'. Business visitors are provided with a variety of valuable, first-hand information, tailored to their specific needs. Furthermore, visitors can get a feel for the brand and its employees which other marketing instruments can hardly provide. Our findings also provided much confidence in that B2B brand worlds are not a fad, but an emerging management instrument that is here to stay. They are the three-dimensional business card of a well-run business.

Appendix A. Company informant statements and motive categories $(n=18)$

"So, we typically want to highlight and show off our global offering, and maybe the customers come here to speak about one Product piece of equipment and then we expand their horizons to the whole portfolio." (Eric, operating company) Awareness

"And what are we doing? Maybe we're feeding the imagination on that to say: 'Oh, I didn't even know you had that.' Okay, great, that's all we need. It's planting the seeds." (Doug, operating company)

"Especially, for some of those who are maybe in procurement for some of our customer companies, or that they're in the Product engineering portion, but not the operations portion. So, they may work day in day out in terms of specifying this product, or Experience they're seeing this equipment on the computer screen or on paperwork or things. But they may literally never have seen it in real life." (Cara, operating company)

"So, they can go play with it [the product] and see what it sounds like when it opens and closes and you're gonna have, you're gonna immerse yourself in a much better experience that way. Better learning. [...] We're after a certain experience and we want to do that globally. Kind of like at Disney. [...] And this is Disney World for [our industry]." (Eric, operating company) "That is very, I would say, very important to project [the brand] as the reliable partner in [our industry]." (Alex, operating company)

"In the B2B area, especially in our industry, aspects such as durability, reliability, and the fact that we developed our competence over many years, are extremely important. And we just convey these aspects this way. [...] And this really is the core aspect that we bring to bear during our brand world tours." (Karl, operating company)

"It's also a bit of sizing each other up and inspecting each other, and it is, let's say, like at the beginning of a private relationship. You have to get to know each other and get a feel for each other, and I think when someone sees us at work here, then they can get a feel for us quite well." (Anna, operating company)

"It is about giving the brand and the company a face. With the employees who are here. So, this is [the brand] in the flesh. [...] It is supposed to make [the brand] tangible and also perceptible here at the site for someone who maybe only knows the product." (Heather, operating company)

"I mean I would say the awareness... Awareness is the starting point and it certainly drives everything else." (Cara, operating company)

"And it's a very... for the breadth that [the brand] has, this is a very quick way to see just how much our company can do, is capable of, how diverse our portfolio is. And I don't think anybody looking at the website or watching one of our many fine YouTube videos... And even it's really hard to show that even at our trade show. But I think [...] that this space gives that picture more effectively than anything I can think of off the top of my head." (Cara, operating company)

Appendix B. Expectations and demands of B2B brand world business visitors $(n=14)$

\begin{tabular}{lc}
\hline Informant statements & Expectation/demand category \\
\hline "To get a good overview of the supplier's products in a short amount of time." (Diane, visitor) & Getting to know the products and \\
"I would then want to get a very good overview of the whole portfolio the brand has on offer, that at offerings \\
least, let's say, all product families, maybe not all product variants in the smallest details, but all \\
product families are presented to me. And I would want to see these products in their application as \\
well, if possible." (Ashley, visitor)
\end{tabular}


"Basically, my expectations as purchasing agent, I want to, I go visit the supplier and I want to understand who the supplier is, what he's capable of and where his strengths are." (Chris, visitor) "So, for me, the history is important, because that in the end is also the root of what they're doing today. 'Where do I come from, where do I want to go?' And this has to fit together also, in my opinion. Therefore, it does play role for me. This also has to do with authenticity. [...] In the end again to get an understanding and to see, whether this brand is actually authentic for the company, and whether you can have trust in them. And history for me is a part of that." (Frank, visitor)

"That means that what I want is a fun, learning gain in understanding along the lines of 'Oh cool, now I Learning, understanding, curiosity also know how that works'." (Betty, visitor)

"So first I have the expectation that the brand world addresses me emotionally, even if it is about a B2B Emotional appeal product." (Betty, visitor)

"The first thing that comes to my mind: I, as a customer, want to feel good. So, I want to feel appreciated, also that I am allowed to go in there, so to say. So, a good personal care then on-site." (Ed, and appreciation visitor)

"Well my expectations, the main thing was just to learn some new [applications in product training]." Product training (Isaac, visitor)

"Well, for one that it looks inviting in the sense of a clear spatial design, really based on the first impression, that it is bright and that there is nothing that distracts me from the products." (Ashley,

Expectations regarding the design visitor)

"Part of the products are really complex and sometimes you don't even know how the products interact Clear and open communication and collude with each other. So, a well-arranged and clear communication of what the products can do, and also somehow in action, in the best case." (Amy, visitor)

"And of course, I expect to see the production process, which production technologies do they use." Factory visit (Chris, visitor)

\section{Appendix C. Value of the B2B brand world experience for business visitors $(n=14)$}

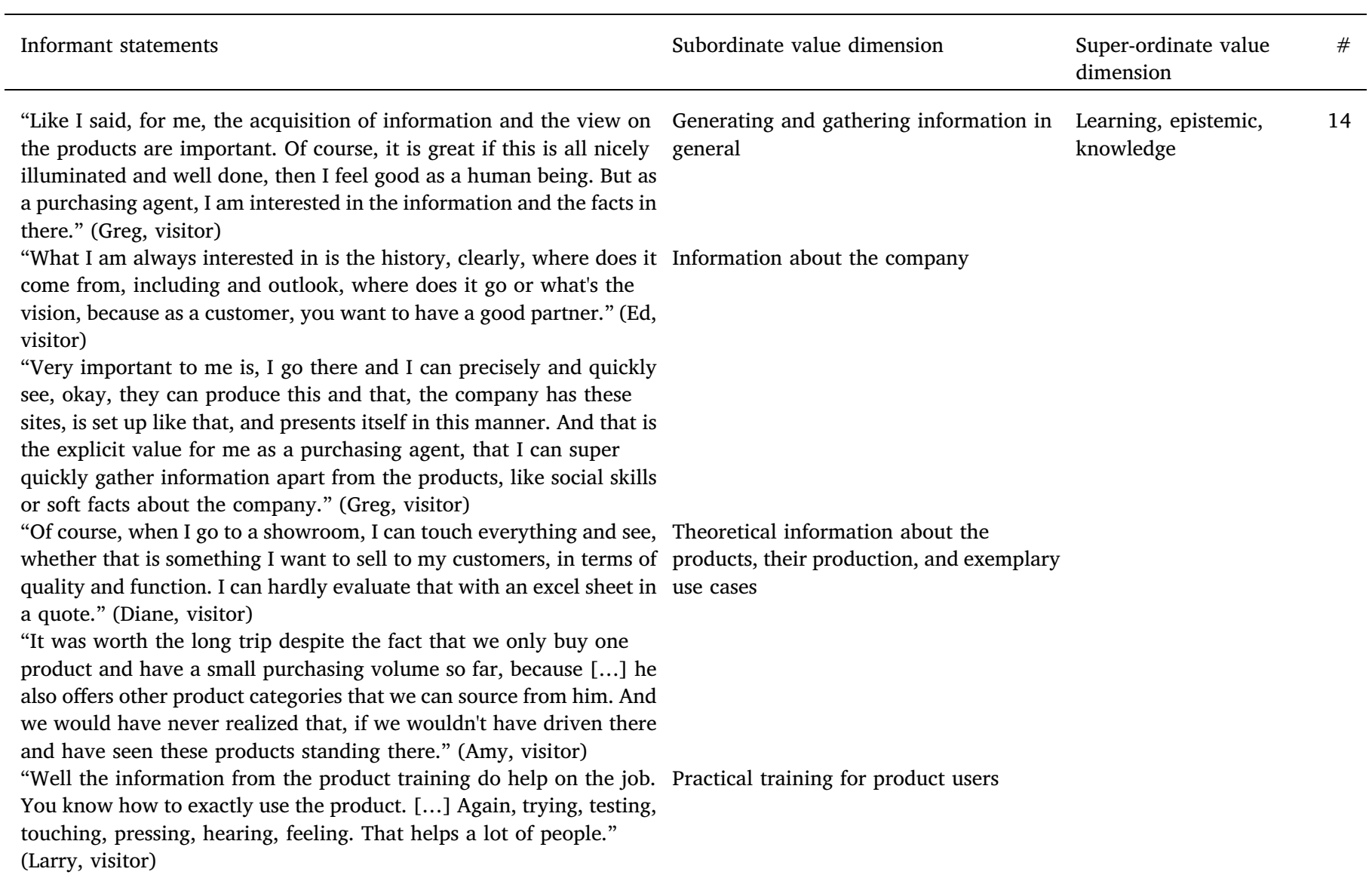


"For me personally and my goals it is very positive, because I can easily gather information there, also for negotiations for example. [...] So, for my own attainment it is extremely effective, but also for the company. Because my personal goals of course flow into the corporate goals." (Greg, visitor)

"The visit has to serve a purpose. Because otherwise I my time is too Functional/utilitarian value valuable for doing this globetrotter thing and looking at something." (Chris, visitor)

"For me as a purchaser it's not so much about prices, but rather about what the company is capable of. Because we are also instructed to minimize the number of suppliers, and if I don't know what they are capable of, then it does help me to see it with my own eyes and have presented nicely what else there is in the supplier." (Amy, visitor)

"It has to appeal to me emotionally. [...] It doesn't only have to be fun Edutainment/Enthusiasm and nice, but I also have to be given information. Ideally in a way so that I do understand something quickly, that I wouldn't have understood as quickly without the brand world. [...] An increase in my enthusiasm for the products, let's say enthusiasm." (Betty, visitor) "To be honest, it was also an appreciation that they took the time for Sense of appreciation and well-being us to show us the brand world." (Betty, visitor)

"I feel treated well and I feel appreciated as a customer and partner." (Ed, visitor)

"It's a kind of emotional bond somehow. I think that when you have tried the products yourself, you emotionally bind to that product much more. [...] Yes, afterwards it was really easy for me to make a product choice. That was really quick then. Before, I got some excelsheets from a lot of suppliers where everything was listed, and I was going back and forth through them, but couldn't really bring myself to make a decision. And after the showroom, that's relatively easy." (Diane, visitor)

"Yes, trying out stays on your mind much more than just looking at some products." (Amy, visitor)

"But it's just nice also to do some other things than at work, where you sometimes only do dreary things [...]. And then you can just do something else for once. And for that, I think these product trainings are also really nice and good. You really get to see something else." (Ken, visitor)

"The integration of a $\mathrm{B} 2 \mathrm{~B}$ product in a $\mathrm{B} 2 \mathrm{C}$ product is something you see a lot, and it is of course highly emotional, when you then see what you do actually have in daily use. I think everyone links this to his own life a bit then. 'Where have I seen that product already, where did I experience it and where not?"' (Greg, visitor)

"I just get a feel for it and this trust is just important, that you know Building trust where they come from, what was their idea, to what extent did they keep up and develop themselves further. So, it's about building trust and minimizing risk." (Amy, visitor)

"For me the goal is to get to know the supplier better and to

understand, what he does, how he does it, and also does he live up to his promises. Because one thing is the spoken word, but how do they put it, 'walk the talk', so what is really behind all that." (Chris,

visitor)

“That I just get a first impression that signals me 'okay', or that I can Building a relationship

make an assessment whether that company is relevant for me or not.

Along the lines of 'do I want to establish a customer relationship with them or rather not?"' (Ashley, visitor)

"Yes, I mean in the end, usually I'm accompanied when I go to a showroom or look at the products. And simply this positive aspect to get into a conversation with the company employees, just to get a feel interpersonally, that is positive for me." (Ashley, visitor)
Value for the own company and the own Professional customers

Emotions as support for remembrance and decision-making

Escapism

Connection to daily life

(1)

Relationship 
"As I just mentioned, because I rejoice in technically complex products, well designed products, honestly also because of the respect that I have for good engineering. And I just rejoice in seeing that someone thought about a good product and that it turned out like that as well. That did play a role. But I did not see it as a tourist attraction, like the typical visitor to an [automotive museum], in that sense." (Betty, visitor)

"I am just someone who likes to try things herself really, and that can lead to me having, when it is a really good product which is good to use, it can lead to me having a real wow factor." (Diane, visitor) "That I'm just sold on them showing me all that. Just for them to differentiate themselves and to impress me with it." (Ashley, visitor) "For me it's just really important to visit these showrooms once a year per supplier, at least, just to have been there and to really see all the new products there again." (Diane, visitor)

"I mainly thought, 'well, they will just sell the [products they are well-known for]'. Like that, what you know. But then it emerged that they do [other product groups] as well, and everything that comes with it. And that was really something where I thought, 'oh okay, I didn't know that you can also buy that from them." (Matt, visitor) "Based on that you can expand your own offer, if you know what else is out there. And then you can just differentiate yourself more." (Ken, visitor)

"Well I first told my wife about it. [...] So, she was the first, and then I also told my father, because he ... I did train as a [job] at his company and worked for him as well. And that was also really interesting for him, the things that I heard and learned there." (Matt, visitor)
Hedonic, altruistic, entertainment, service excellence

Innovation

Reputation, status, esteem, branding

Social

\section{Appendix D. Informant statements on the B2B brand world content}

Informant statements

"So, this is [the brand] in the flesh. [...] It is supposed to make [the brand] tangible and also perceptible here at the site for someone who maybe only knows the product." (Heather, operating company)

"Coming back to the [credo of the company], I mean, the content basically is on the one hand, the brand itself, its core and values, everything the brand has so far in this respect. And you just have to live up to that and the content is basically everything that the brand has to offer." (Bob, exhibition designer)

"It is about giving the brand and the company a face. With the employees who are here." (Heather, operating company)

"These locations also give the opportunity for personal interactions. I am able to retreat into a lounge and have a coffee upstairs, and those are often also the things that are much more exciting with regards to testing and establishing a relationship, than just directly next to some product highlights. And there also has to be time for that, because these personal relationships are the alpha and omega of not only a purchase, but also a re-purchase and a recommendation, continuous collaboration and consistent joint growth." (Quentin, operating company)

"[Personal experience] plays a huge role. [...] Customers can't please us more as than to actually demand this, being willing to do it and also doing it in the end, testing the products, and wanting to work with them. And there is nothing that can replace that experience. No brochure, no video, no picture, no text. Only the personal experience can do that." (Peter, operating company)

"Then this hands-on practical experience, definitely. Everything I can do myself or touch is good. I can feel the materials, get a feeling for the quality, whether everything is well built and the workmanship is good." (Ashley, visitor)

"This knowledge transfer also plays a role in there. Training customers in dedicated training centers, but also 'how the products are used properly', and 'how certain processes are executed'. That's a big thing. And when I think about [one brand world] to convey this knowledge to the visitor, to even make them understand complex connections. [...] And if I as a customer realize that I really learn something when I go there, then I really take something out of it and that of course also strengthens the customer relationship." (Craig, exhibition designer)

\section{Content category}

Experience the brand, its core and values "in-vivo" by making it tangible

Experience and understand the products first-hand Experience and understand the products first-hand

\author{
(1)
}
with employees
Giving the brand a face through personal interaction

Deep, detailed, precise educational process 
"On the one hand, we have the finished product right here, with a problem solution, but we also have the base product right there. So, I can exactly see how it is build and how the components are put together. And if someone wants to get more into the details, we can access the production lines, so it is a very transparent thing for the customer. I think that that is an important success factor." (Luke, operating company)

"That is very, I would say, very important to project [the brand] as the reliable partner in [our industry]." (Alex, operating company)

"And the goal is then, I would say, to convince the visitor that you are the right partner. That means that you cannot just superficially present what you can do, but you really have to go into the details." (Bob, exhibition designer)

"The sales guys know their audience quite well, they know that one guy likes this more Individualizing the content to suit the visitor's needs and another that. For example, what I like to do is that I consciously split up groups. And and expectations

then I go see one thing with the purchasing agents and let the quality managers go play with our quality managers. They really go into our production lines then, wear gloves, crawl into our lines and so on, and with the purchasing agents we only do a rough overview, so that they get an idea for the costs or something like that. And it really has to be individualized for everyone." (Anna, operating company)

"An individual approach in the sense, I'm a purchasing agent for two product groups. And I don't need to see production lines from products I don't buy. Doesn't interest me. That's a waste of time for me, I don't have any stakes in that." (Chris, visitor)

"I think you need to look at the target group intensively, and what kind of people they are. [...] A typical example, whether I have an engineer visiting me or a marketing person. They have completely different needs and also a different eye, as they put it. Meaning that they perceive things differently, the same object differently. And therefore, I also have to tell them different things." (David, exhibition designer)

"It's about exemplary things, the relevant things. I think that's a big success factor we can put above everything, relevance. If it doesn't affect me personally and doesn't bring me forward, then I can just chuck it in the dustbin. Then I don't even need to come. I would go out on a limb for this here." (Craig, exhibition designer)

"The first thing that comes to my mind: I, as a customer, want to feel good. So, I want to feel appreciated, also that I am allowed to go in there, so to say. So, a good personal care then on-site." (Ed, visitor)

"First of all, I think that it is important that the customer feels that he is being courted, so to say. He has to be able to feel well, and also to let go to a certain extent. You can talk extensively about everything. So that the visitor gets the feeling that you take the time for him". (Luke, operating company

"In the B2B area, especially in our industry, aspects such as durability, reliability, and the fact that we developed our competence over many years, are extremely important. And we just convey these aspects this way. [...] And this really is the core aspect that we bring to bear during our brand world tours." (Karl, operating company)

"So, for me, the heritage is indeed important, because it shows the origin basically of what they do today, as well. Where do I come from, where do I want to go? And I think that the two have to fit together, somehow, and that is why it plays an important role for me. That also has something to do with authenticity." (Frank, visitor)

"The center does the work for us. Especially if you've got somebody who's an engineer or Emotionalizing, fascinating and immersing the visitor if they're working in a company that we're dealing with, doing the types of work that they're going to be in here for, this stuff is going to catch their attention. This is the stuff that's cool. This is the reason that they went into the business that they went into and took the life path that they took. This gets their attention. And even if they only stop for a second to look at it on their way back, you still planted that seed." (Cara, operating company)

"So first I have the expectation that the brand world addresses me emotionally, even if it is about a B2B product." (Betty, visitor)

"I think for industrial companies, when we talk about adding emotional appeal, it is really really essential, also if maybe not as essential as in B2C, but it nevertheless has to be there." (Craig, exhibition designer)

"It really first and foremost is about immersing and getting involved in a topic, as opposed to just being presented with it." (Craig, exhibition designer)

"The first thing is the immersive experience. The opportunity we have with this multidimensional, spatial communication which brand worlds belong to... you just have to try and exploit it. Nowhere else you have this opportunity of being that much face-toface with the customer as you are in the brand world. [...] And then you're only successful if you achieve this, to immerse people, involve them, get their interest, so that the things stick." (Alan, exhibition designer)

"Authenticity, trust, and I think in the setting of customer visits, to get in touch with different departments, it provides the opportunity to personally interact and getting to

Positioning the brand as the right partner for the visitor who understands his needs

Making the visitor feel special, appreciated, and esteemed

\section{.}

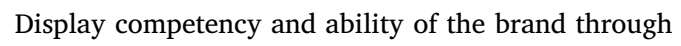
history/heritage, present, and future 
know people and to see, how trustworthy the things are that we tell." (Bill, operating company)

"I would say, the more authentic I can describe a brand, the better I can identify myself with it and the more trust I develop towards this brand. [...] When I achieve that, to create authenticity in a good way, I think then they accomplished a lot." (Frank, visitor) "Well, it has to do with the entire story that I build, the space that I build, the design I create, that all this combines into an authentic overall picture. Most of the time, authenticity is the most important thing." (Bob, exhibition designer)

"Nowhere else do you have this opportunity of being that much face-to-face with the customer as you are in the brand world. From all formats, beginning with TV advertising where you reach millions of people, but of course also the sustainability is lower. Then on the other side of the spectrum you have these brand worlds, or the face-to-face product presentation, where you stand face-to-face with your customer or your visitor, and where you can pull out all the stops." (Alan, exhibition designer)

"And I think a brand world or a showroom offers that definitely, this chance, and it has this power, because I really do have the customer in my 'world', and he doesn't see the competitor logo shimmer through somewhere. He really is completely with me." (David, exhibition designer)

"Since we're talking about industrial goods, it is about presenting them short, succinct, Identification of the brand with visitor's daily life and let's also really say sexy. Sexy meaning that it has to be presented in a way that you understand the reason behind it, and why you need it. Basic selling. And industrial goods are even slightly more interesting, when they are integrated in their final purpose. So, when we make a consumer good out of it and present there where the parts go into." (Greg, visitor)

"For example, when I present [a certain product], it really looks quite unspectacular by itself, and it might also be hard to understand, or even to have an interest, what this really is. When I now put this product into a final use case that I know as a consumer, though, or even better into a working cutaway model, and present it like that, then it is much easier for me to understand, to be interested, and also to even get excited about it." (Frank, visitor)
Be face-to-face with the visitor

Appendix E. Informant statements on the B2B brand world experiencescape

\begin{tabular}{|c|c|c|}
\hline Informant statements & Experiencescape sub-category & $\begin{array}{l}\text { Experiencescape } \\
\text { category }\end{array}$ \\
\hline $\begin{array}{l}\text { "It has to be a harmonious overall picture, where I say "Oh, sure, I can feel } \\
\text { the brand"" (Craig, exhibition designer) } \\
\text { "Best case scenario, the brand world really fits the supplier." (Greg, visitor) }\end{array}$ & Tangible embodiment of the brand & $\begin{array}{l}\text { Artifacts and } \\
\text { spaces }\end{array}$ \\
\hline $\begin{array}{l}\text { "Architecture and design, I think are definitely success factors. That's just a } \\
\text { thing of fascination, I transport a lot of brand attributes with it, and the } \\
\text { whole range of fascination, wow-effects so to say, to the point of } \\
\text { authenticity." (Craig, exhibition designer) } \\
\text { "The first thing is the immersive experience. The opportunity we have with } \\
\text { this multidimensional, spatial communication which brand worlds belong } \\
\text { to... you just have to try and exploit it. (Alan, exhibition designer) }\end{array}$ & $\begin{array}{l}\text { Emotionally appealing, intriguing and immersive } \\
\text { atmosphere }\end{array}$ & \\
\hline $\begin{array}{l}\text { "And then of course with respect to the location, there are several aspects. } \\
\text { For one, like with [exemplary company } 1 \text { or exemplary company 2], I } \\
\text { arrive at the corporate headquarters and the origin of the brand, and then } \\
\text { of course I get a totally different impression, as when I arrived at a dull } \\
\text { production facility in some other city. So, really just visiting these roots } \\
\text { and origins of a brand. I think a lot of understanding and identification } \\
\text { happens there, this 'genius loci' just does play a role." (Craig, exhibition } \\
\text { designer) }\end{array}$ & "Genius Loci" - Location as exp. Value & \\
\hline $\begin{array}{l}\text { "Well, it has to do with the entire story that I build, the space that I build, } \\
\text { the design I create, that all this combines into an authentic overall picture. } \\
\text { Most of the time, authenticity is the most important thing." (Bob, } \\
\text { exhibition designer) }\end{array}$ & $\begin{array}{l}\text { Presentation and content fitting the brand and its } \\
\text { spirit }\end{array}$ & \\
\hline $\begin{array}{l}\text { "Well, it really is decisive for the experience, this multisensory marketing, I } \\
\text { would say, that we try to touch the visitors on all channels. With videos, } \\
\text { the visitor can touch, can try out, and so on. (Ian, operating company) }\end{array}$ & Multisensuality of the exhibits & \\
\hline $\begin{array}{l}\text { "These exhibits are really very close to cutting edge technology, which are } \\
\text { not 'learned' out there. People simply don't know how to use those things. } \\
\text { So, you may not overdo it at that point. If the things are too complicated, }\end{array}$ & Ease of use of the exhibits & \\
\hline
\end{tabular}


it's frustrating, and they won't be used. And of course, it should never be frustrating." (Alan, exhibition designer)

"There is not too much technology in both spaces, everything is easy to use, and it is trying to reduce complex facts and circumstances to a minimum and to a simpler level." (Ian, operating company)

"But it may also not distract too much so that you get the feeling that maybe all these effects and the staging cover up the fact that maybe my machines are not that great. So, it may only support, it may never degenerate into being an end in itself." (Bob, exhibition designer) "Every exhibit should have the goal to convey a process or a product and should end with a learning outcome. That it is easier with this or that product, or only works this and that way. Like in a training. Never as an end in itself." (Alan, exhibition designer)

"There was one [brand world] which I really thought was cluttered. It was Less is more, focus on relevancy a huge room, really too big already, with all the products standing there in line, every possible version there is. And I got really clobbered over the head with that and it did not help me at all. It rather confused me, because it was just too much. Then there also was a different [brand world], where it was really presented nicely. With use cases, the products which are really relevant next to each other, so that you could also compare the products. That really helped. [...] So, I really think that less is more." (Diane, visitor) "We built multiple rooms that can do really different things. And there we don't have the differentiation of the entire setting. The invest is the same for B2C and B2B visitors, but the variation is different, to cater to the needs of the target group. [...] So we built multi-functional rooms with elements that can present different kinds of information or environments. [...] And when you have the B2B mode, then they will of course display information for the B2B visitors, if they have customers there." (Alan, exhibition designer)

„Just the overall impression, from the outside and the inside, should be innovative." (Jade, operating company)

"So, one point I just mentioned is about the general appearance. That it is contemporary and up-to-date, and just appealing in total. The entire setting should just be appealing." (David, exhibition designer)

"Then of course also the cleanliness. How do I enter, how clean is it, is everything working, the exhibitions and so on." (Mike, operating company) "And then I also have the personal demand, that the supplier also presents the products nicely. Although sometimes it might be subjective, I generalize that to the entire company. If he does not take care of his showroom, whether new or old, if that is not taken care of, then how does it look like in production, in storage, how do the products arrive at my facility, how do they pack, how are the logistics? So, I do think that you can infer things, from a tidy front room or a messy one." (Greg, visitor)

"Well, of course the things have to be authentic and consistent there. From Social representation of the brand (Behavioral the optics, to the visual design, to the way we present things there, but of Branding, employee behavior towards visitors) course also how we treat our visitors. So, including corporate behavior

[...]. It is our personal matter, to treat these visitors individually and personally, of course. That is important. (Jade, operating company)

"And our guides are former employees who are now in pension. And they are not grouchy or annoyed, but in contrary, they are happy to be there. So, this representation, they are like ambassadors of our brand. It is about giving the brand and the company a face. With the employees who are here." (Heather, operating company)

"So, we really look for guides who first of all do this on a voluntary basis, Brand World and contents have to be 'lived' who have fun doing it, who are supporters or fans of our company, and where you can see the sparkle in their eyes when they talk about our products." (Ian, operating company)

"I really think all of us stand behind all of this. We do it with a passionate heart and soul, and I hope one can tell that in me as well." (Luke, operating company)

"So, besides the competence and scrupulousness in the doing, our guides also need to have the passion to work in this field" (Brian, operating company)

"But in B2B, you really get a guide normally, or someone as a contact person, who explains everything, presents things, and who is just another level to answer questions, as well. Because all this competency cannot be
Raison d'être for each exhibit

Contemporaneity and up-to-dateness

Cleanliness

Social

environment and practices 
conveyed on a medial level with images and texts, and you cannot present and cover this competency otherwise" (Bob, exhibition designer)

"I think it's incredibly important to have someone there who is experienced Focus on the visitor and his needs in presenting something like that. There are people who are able to do that, and there are people who are not. [...] I think that is important. Someone who gives you a lot of information, but also not too much, but just the right information and the important information, succinct, presented with the product." (Diane, visitor)

\section{Appendix F. Interview guideline for operating companies}

(Sub-questions only asked in case of further inquiries)

1. What are special features of this Brand World?

1.1. What are special content-related features of the Brand World?

1.1.1. Related to the practical/hands-on experience of the visitor?

1.1.2. Related to the education or information of the visitor?

1.1.3. Related to the entertainment of the visitor?

1.1.4. Related to the product range on display in the Brand World?

1.1.5. Related to the time perspective of the Brand World? (Display of present/past/future developments)

1.1.6. Related to additional services for the visitors?

1.2. What are special physical features of the Brand World?

1.2.1. Related to the size?

1.2.2. Related to the location?

1.2.3. Related to the architecture and the design?

1.2.4. Related to the multisensuality of the Brand World?

1.2.5. Related to the investment?

1.3. What are special customer related features of the Brand World?

1.3.1. What target groups are addressed with the Brand World?

1.3.2. What phase of the customer relationship does the Brand World aim at?

(New or existing customers?)

1.3.3. What forms of interaction are there between visitor and company within the Brand World? (Dialectical/Co-Creation)

2. Thinking about the Brand World: What objectives are pursued from the company's perspective?

2.1. What goals are pursued regarding the company image?

2.2. What goals are pursued regarding the customer relationships?

2.3. What goals are pursued regarding the innovations?

2.4. What monetary goals are pursued?

2.5. What goals are pursued regarding collaboration with customers/stakeholders?

2.6. What goals are pursued regarding knowledge transfer?

3 . What value do you want to provide your visitors with the visit of the brand world?

3.1. What value do you want the visitor to derive from the visit?

3.2. To what extent do you want the visit to help the visitor in his business activities?

3.3. To what extent do you want the visit itself be valuable?

3.4. To what extent do you want the visit to influence the visitor himself?

3.5. To what extent do you want the visit to influence other people than the visitor, e.g. within his organization?

3.6. To what extent do you want the visitor to be active during the visit?

3.7. To what extent do you want the visitor to be reactive and rather perceive and observe?

4. From the company's perspective, what are the success factors to achieve these goals with the Brand World?

4.1. What is important to achieve the image related goals?

4.2. What is important to achieve the goals related to the customer relationship?

4.3. What is important to achieve the goals related to innovations?

4.4. What is important to achieve the monetary goals?

4.5. What is important to achieve the goals related to the collaboration with customers/Stakeh.?

4.6. What is important to achieve the goals related to the knowledge transfer?

4.7. What, in total, makes your Brand World successful?

4.8. Why does your Brand World "work" better than other/competitor's Brand Worlds?

4.9. Which aspect of your Brand World are you especially proud of?

4.10. What part of your Brand World would you change or improve?

\section{Appendix G. Interview guideline for business visitors}

(Sub-questions only asked in case of further inquiries) 
1. Which B2B brand worlds have you visited as a customer/visitor so far?

2. Please describe these B2B brand worlds briefly

3. What was the reason for your visit to these B2B brand worlds?

4. When was your last visit to such a B2B brand world?

5 . What are your expectations of a B2B brand world from the customer perspective?

6. What did you perceive during your visit and how did you perceive it? (in case of visits of various brand worlds:)

6.1. How do the brand worlds that you visited differ from each other? (related to the content)

6.1.1. Related to the practical/hands-on experience of the visitor?

6.1.2. Related to the education or information of the visitor?

6.1.3. Related to the entertainment of the visitor?

6.1.4. Related to the product range on display in the Brand World?

6.1.5. Related to the time perspective of the Brand World? (Display of present/past/future developments)

6.1.6. Related to additional services for the visitors? (related to physical features)

6.1.7. Related to the size?

6.1.8. Related to the location?

6.1.9. Related to the architecture and the design?

6.1.10. Related to the multisensuality of the Brand World?

7. Which value do business visitors derive from the visit of a B2B brand world of a company?

7.1. What makes the visit valuable for the visitor?

7.2. To what extent did the visit help you in your business activities?

7.3. To what extent was the visit itself valuable to you?

7.4. To what extent did your visit influence yourself?

7.5. To what extent did your visit influence other people, e.g. within your organization?

7.6. To what extent were you active during the visit?

7.7. To what extent were you reactive, perceiving, or observing?

8. From the visitor's perspective, what are the success factors of B2B brand worlds?

8.1. What did you like about the brand world especially?

(related to the content)

8.1.1. Related to the practical/hands-on experience of the visitor?

8.1.2. Related to the education or information of the visitor?

8.1.3. Related to the entertainment of the visitor?

8.1.4. Related to the product range on display in the Brand World?

8.1.5. Related to the time perspective of the Brand World? (Display of present/past/future developments)

8.1.6. Related to additional services for the visitors? (related to physical features)

8.1.7. Related to the size?

8.1.8. Related to the location?

8.1.9. Related to the architecture and the design?

8.1.10. Related to the multisensuality of the Brand World?

8.2. What would you change or improve?

(related to the content)

8.2.1. Related to the practical/hands-on experience of the visitor?

8.2.2. Related to the education or information of the visitor?

8.2.3. Related to the entertainment of the visitor?

8.2.4. Related to the product range on display in the Brand World?

8.2.5. Related to the time perspective of the Brand World? (Display of present/past/future developments)

8.2.6. Related to additional services for the visitors? (related to physical features)

8.2.7. Related to the size?

8.2.8. Related to the location?

8.2.9. Related to the architecture and the design?

8.2.10. Related to the multisensuality of the Brand World?

8.3. What has to be done to fulfill your expectations towards a B2B brand world?

8.3.1. What has to be done to exceed your expectations towards a B2B brand world?

9. If you have visited several brand worlds: If so, why did the brand world of one company "work" better than the one of another company?

\section{Appendix H. Interview guideline for exhibition designers}

(Sub-questions only asked in case of further inquiries) 
1. Which B2C and B2B brand worlds have you worked on as an exhibition designer so far?

2. Please describe these $\mathrm{B} 2 \mathrm{~B}$ brand worlds briefly

3. What are the differences between $\mathrm{B} 2 \mathrm{C}$ and $\mathrm{B} 2 \mathrm{~B}$ brand worlds?

3.1. Content-related?

3.2. Related to physical features?

3.3. Which differences emerge from the different contexts of B2C and B2B?

4. Which objectives and motives do B2C companies have with their brand worlds?

4.1. What goals are pursued regarding the company image?

4.2. What goals are pursued regarding the customer relationships?

4.3. What goals are pursued regarding the innovations?

4.4. What monetary goals are pursued?

4.5. What goals are pursued regarding collaboration with customers/stakeholders?

4.6. What goals are pursued regarding knowledge transfer?

5. Which objectives and motives do B2B companies have with their brand worlds?

5.1. What goals are pursued regarding the company image?

5.2. What goals are pursued regarding the customer relationships?

5.3. What goals are pursued regarding the innovations?

5.4. What monetary goals are pursued?

5.5. What goals are pursued regarding collaboration with customers/stakeholders?

5.6. What goals are pursued regarding knowledge transfer?

6. What value do B2C companies want to offer their visitors with their brand worlds?

6.1. What value do they want the visitor to derive from the visit?

6.2. To what extent do they want the visit to help the visitor in achieving a goal?

6.3. To what extent do they want the visit itself be valuable?

6.4. To what extent do they want the visit to influence the visitor himself?

6.5. To what extent do they want the visit to influence other people than the visitor, e.g. within his environment?

6.6. To what extent do they want the visitor to be active during the visit?

6.7. To what extent do they want the visitor to be reactive and rather perceive and observe?

7. What value do B2B companies want to offer their visitors with their brand worlds?

7.1. What value do they want the visitor to derive from the visit?

7.2. To what extent do they want the visit to help the visitor in achieving a goal?

7.3. To what extent do they want the visit itself be valuable?

7.4. To what extent do they want the visit to influence the visitor himself?

7.5. To what extent do they want the visit to influence other people than the visitor, e.g. within his environment?

7.6. To what extent do they want the visitor to be active during the visit?

7.7. To what extent do they want the visitor to be reactive and rather perceive and observe?

8. From the exhibition designer's perspective, what are the success factors of B2B brand worlds?

(related to the content)

8.1. Related to the practical/hands-on experience of the visitor?

8.2. Related to the education or information of the visitor?

8.3. Related to the entertainment of the visitor?

8.4. Related to the product range on display in the Brand World?

8.5. Related to the time perspective of the Brand World?

(Display of present/past/future developments)

8.6. Related to additional services for the visitors? (related to physical features)

8.7. Related to the size?

8.8. Related to the location?

8.9. Related to the architecture and the design?

8.10. Related to the multisensuality of the Brand World?

9. What specifics have to be taken into account in the design of B2B brand worlds?

(related to the content)

9.1. Related to the practical/hands-on experience of the visitor?

9.2. Related to the education or information of the visitor?

9.3. Related to the entertainment of the visitor?

9.4. Related to the product range on display in the Brand World?

9.5. Related to the time perspective of the Brand World? (Display of present/past/future developments)

9.6. Related to additional services for the visitors? (related to physical features)

9.7. Related to the size?

9.8. Related to the location?

9.9. Related to the architecture and the design?

9.10. Related to the multisensuality of the Brand World?

10. What difficulties arise when designing B2B brand worlds? 


\section{References}

Aaker, D. A. (1991). Managing brand equity: Capitalizing on the value of a brand name. New York, Toronto, New York: Free Press; Maxwell Macmillan Canada; Maxwell Macmillan International.

Aaker, D. A. (1996). Measuring brand equity across products and markets. California Management Review, 38(3), 102-120.

Agapito, D., Valle, P., \& Mendes, J. (2014). The sensory dimension of tourist experiences: Capturing meaningful sensory-informed themes in Southwest Portugal. Tourism Management, 42, 224-237. http://dx.doi.org/10.1016/j.tourman.2013.11.011.

Albers, S., Mantrala, M. K., \& Sridhar, S. (2010). Personal selling elasticities: A metaanalysis. Journal of Marketing Research, 47(5), 840-853. http://dx.doi.org/10.1509/ jmkr.47.5.840.

Andersen, P. H., \& Kumar, R. (2006). Emotions, trust and relationship development in business relationships: A conceptual model for buyer-seller dyads. Industrial Marketing Management, 35(4), 522-535. http://dx.doi.org/10.1016/j.indmarman. 2004.10.010.

Andrews, L., Kiel, G., Drennan, J., Boyle, M. V., \& Weerawardena, J. (2007). Gendered perceptions of experiential value in using web-based retail channels. European Journal of Marketing, 41(5/6), 640-658. http://dx.doi.org/10.1108/03090560710737660.

Arnould, E. J., Price, L., \& Zinkhan, G. M. (2004). Consumers. McGraw-Hill/Irwin series in marketing(2. ed.). Boston, Mass: McGraw-Hill/Irwin.

Babin, B. J., Darden, W. R., \& Griffin, M. (1994). Work and/or fun: Measuring hedonic and utilitarian shopping value. Journal of Consumer Research, 20(4), 644. http://dx. doi.org/10.1086/209376.

Backhaus, K., Steiner, M., \& Lügger, K. (2011). To invest, or not to invest, in brands? Drivers of brand relevance in B2B markets. Industrial Marketing Management, 40(7), 1082-1092. http://dx.doi.org/10.1016/j.indmarman.2011.09.002.

Ballantyne, D., \& Aitken, R. (2007). Branding in B2B markets: Insights from the servicedominant logic of marketing. Journal of Business \& Industrial Marketing, 22(6), 363-371. http://dx.doi.org/10.1108/08858620710780127.

Bendixen, M., Bukasa, K. A., \& Abratt, R. (2004). Brand equity in the business-to-business market. Industrial Marketing Management, 33(5), 371-380. http://dx.doi.org/10. 1016/j.indmarman.2003.10.001.

Bengtsson, A., \& Servais, P. (2005). Co-branding on industrial markets. Industria Marketing Management, 34(7), 706-713. http://dx.doi.org/10.1016/j.indmarman. 2005.06.004.

Berry, L. L., \& Carbone, L. P. (2002). Managing the total customer experience. MIT Sloan Management Review, 43(3), 85-89.

Beverland, M. B., Napoli, J., \& Lindgreen, A. (2007). Industrial global brand leadership: A capabilities view. Industrial Marketing Management, 36(8), 1082-1093. http://dx.doi. org $/ 10.1016 / \mathrm{j}$.indmarman.2006.08.007.

Biedenbach, G., \& Marell, A. (2010). The impact of customer experience on brand equity in a business-to-business services setting. Journal of Brand Management, 17(6), 446-458. http://dx.doi.org/10.1057/bm.2009.37.

Bitner, M. J. (1990). Evaluating service encounters: The effects of physical surroundings and employee responses. Journal of Marketing, 54(2), 69. http://dx.doi.org/10.2307/ 1251871.

Bitner, M. J. (1992). Servicescapes: The impact of physical surroundings on customers and employees. Journal of Marketing, 56(2), 57. http://dx.doi.org/10.2307/1252042.

Bogner, A., Littig, B., \& Menz, W. (Eds.). (2009). Interviewing experts. Research methods series. Basingstoke [England], New York: Palgrave Macmillan.

Bogner, A., \& Menz, W. (2009). The theory-generating expert interview: Epistemological interest, forms of knowledge, interaction. In A. Bogner, B. Littig, \& W. Menz (Eds.). Research methods series. Interviewing experts (pp. 43-80). Basingstoke [England], New York: Palgrave Macmillan.

Borders, A. L., \& Kemp, E. A. (2018). Editorial on the role of emotions in B2B marketing Guest editorial Journal of Business \& Industrial Marketing, 33(1), 1-2. http://dx.doi. org/10.1108/JBIM-06-2017-0126.

Borghini, S., Diamond, N., Kozinets, R. V., McGrath, M. A., Muñiz, A. M., \& Sherry, J. F., Jr. (2009). Why are themed Brandstores so powerful? Retail brand ideology at American girl place. Journal of Retailing, 85(3), 363-375. http://dx.doi.org/10.1016/ j.jretai.2009.05.003.

Brakus, J. J., Schmitt, B. H., \& Zarantonello, L. (2009). Brand experience: What is it? How is it measured? Does it affect loyalty? Journal of Marketing, 73(3), 52-68. http://dx. doi.org/10.1509/jmkg.73.3.52.

Brown, B. P., Bellenger, D. N., \& Johnston, W. J. (2007). The implications of business-tobusiness and consumer market differences for B2B branding strategy. Journal of Business Market Management, 1(3), 209-230. http://dx.doi.org/10.1007/s12087-0070011-x.

Brown, B. P., Zablah, A. R., Bellenger, D. N., \& Donthu, N. (2012). What factors influence buying center brand sensitivity? Industrial Marketing Management, 41(3), 508-520. http://dx.doi.org/10.1016/j.indmarman.2011.06.008.

Cañal-Bruland, R., \& van der Kamp, J. (2015). Embodied perception: A proposal to reconcile affordance and spatial perception. Perception, 6(2), 63-66. http://dx.doi.org 10.1068/i0709jc.

Carù, A., \& Cova, B. (2003). Revisiting consumption experience: A more humble but complete view of the concept. Marketing Theory, 3(2), 267-286. http://dx.doi.org/10. $1177 / 14705931030032004$

Carù, A., \& Cova, B. (2007). Consuming experiences: An introduction. In A. Carù, \& B. Cova (Eds.). Consuming experience (pp. 3-16). (1 $1^{\text {st }}$ ed.). London: Routledge.

Collins, C. J. (2007). The interactive effects of recruitment practices and product awareness on job seekers' employer knowledge and application behaviors. The Journal of Applied Psychology, 92(1), 180-190. http://dx.doi.org/10.1037/0021-
9010.92.1.180.

Cretu, A. E., \& Brodie, R. J. (2007). The influence of brand image and company reputation where manufacturers market to small firms: A customer value perspective. Industrial Marketing Management, 36(2), 230-240. http://dx.doi.org/10.1016/j.indmarman. 2005.08.013.

Davis, D. F., Golicic, S. L., \& Marquardt, A. J. (2008). Branding a B2B service: Does a brand differentiate a logistics service provider? Industrial Marketing Management, 37(2), 218-227. http://dx.doi.org/10.1016/j.indmarman.2007.02.003.

Diamond, N., Sherry, J. F., Jr., Muñiz, A. M., McGrath, M. A., Kozinets, R. V., \& Borghini, S. (2009). American girl and the brand gestalt: Closing the loop on sociocultural branding research. Journal of Marketing, 73(3), 118-134. http://dx.doi.org/10.1509/ jmkg.73.3.118.

Dolbec, P.-Y., \& Chebat, J.-C. (2013). The impact of a flagship vs. a brand store on brand attitude, brand attachment and brand equity. Journal of Retailing, 89(4), 460-466. http://dx.doi.org/10.1016/j.jretai.2013.06.003.

Dourish, P. (2004). Where the action is: The foundations of embodied interaction. A Bradford book(1. MIT Press paperback ed.). Cambridge, Mass: MIT Press.

Ekman, P. (1992). An argument for basic emotions. Cognition \& Emotion, 6(3-4), 169-200.

Flick, U. (2009). An introduction to qualitative research (4. ed., rev., expanded and updated). Los Angeles, Calif: SAGE.

Fournier, S. (1998). Consumers and their brands: Developing relationship theory in consumer research. Journal of Consumer Research, 24(4), 343-353. http://dx.doi.org/ 10.1086/209515

Gainer, B. (1995). Ritual and relationships: Interpersonal influences on shared consumption. Journal of Business Research, 32(3), 253-260. http://dx.doi.org/10.1016/ 0148-2963(94)00050-O.

Geiger, I. (2017). A model of negotiation issue-based tactics in business-to-business sales negotiations. Industrial Marketing Management, 64, 91-106. http://dx.doi.org/10. 1016/j.indmarman.2017.02.003.

Gentile, C., Spiller, N., \& Noci, G. (2007). How to sustain the customer experience. European Management Journal, 25(5), 395-410. http://dx.doi.org/10.1016/j.emj. 2007.08.005.

Gibson, J. J. (1986). The ecological approach to visual perception. New York: Psychology Press.

Gilmore, J. H., \& Pine, B. J. (2002). Customer experience places: The new offering frontier. Strategy \& Leadership, 30(4), 4-11. http://dx.doi.org/10.1108/ 10878570210435306

Gomes, M., Fernandes, T., \& Brandão, A. (2016). Determinants of brand relevance in a B2B service purchasing context. Journal of Business \& Industrial Marketing, 31(2), 193-204. http://dx.doi.org/10.1108/JBIM-08-2014-0151.

Gordon, G. L., Calantone, R. J., \& Di Benedetto, C. A. (1993). Brand equity in the businessto-business sector. The Journal of Product and Brand Management, 2(3), 4-16. http:/ dx.doi.org/10.1108/10610429310046689.

Gorley, K. G., \& Gioia, D. A. (2004). Identity ambiguity and change in the wake of a corporate spin-off. Administrative Science Quarterly, 49(2), 173-208.

Grewal, D., Krishnan, R., Baker, J., \& Borin, N. (1998). The effect of store name, brand name and price discounts on consumers' evaluations and purchase intentions. Journal of Retailing, 74(3), 331-352. http://dx.doi.org/10.1016/S0022-4359(99)80099-2.

Håkansson, H. (Ed.). (1982). International marketing and purchasing of industrial goods: An interaction approach (repr). New York: John Wiley \& Sons.

Håkansson, H., \& Snehota, I. (Eds.). (1995). Developing relationships in business networks(1. ed., 1. publ). London u.a: Routledge.

Helkkula, A., Kelleher, C., \& Pihlström, M. (2012). Characterizing value as an experience: Implications for service researchers and managers. Journal of Service Research, 15(1), 59-75. http://dx.doi.org/10.1177/1094670511426897.

Hoch, S. J. (2002). Product experience is seductive. Journal of Consumer Research, 29(3), 448-454. http://dx doi org/10.1086/344422.

Holbrook, M. B. (1999). Introduction to consumer value. In M. B. Holbrook (Ed.) Routledge interpretive marketing research series. Consumer value: A framework for analysis and research (pp. 1-28). (1st ed.). London u.a.: Routledge.

Holbrook, M. B., \& Hirschman, E. C. (1982). The experiential aspects of consumption: Consumer fantasies, feelings, and fun. Journal of Consumer Research, 9(2), 132-140. http://dx.doi.org/10.1086/208906.

Hollenbeck, C. R., Peters, C., \& Zinkhan, G. M. (2008). Retail spectacles and brand meaning: Insights from a Brand Museum case study. Journal of Retailing, 84(3), 334-353. http://dx.doi.org/10.1016/j.jretai.2008.05.003.

Hutton, J. G. (1997). A study of brand equity in an organizational-buying context. The Journal of Product and Brand Management, 6(6), 428-439. http://dx.doi.org/10.1108/ 10610429710190478 .

Interbrand (2016). Best global brands 2016: Anatomy of growth. Retrieved from www. bestglobalbrands.com.

Jain, R., Aagja, J., \& Bagdare, S. (2017). Customer experience: A review and research agenda. Journal of Service Theory and Practice, 27(3), 642-662. http://dx.doi.org/10. 1108/JSTP-03-2015-0064.

Jelić, A., Tieri, G., de Matteis, F., Babiloni, F., \& Vecchiato, G. (2016). The enactive approach to architectural experience: A neurophysiological perspective on embodiment, motivation, and affordances. Frontiers in Psychology, 7(481), 1-20. http://dx. doi.org/10.3389/fpsyg. 2016.00481.

Joy, A., Wang, J. J., Chan, T.-S., Sherry, J. F., Jr., \& Cui, G. (2014). M(art)worlds: Consumer perceptions of how luxury Brand Stores become art institutions. Journal of Retailing, 90(3), 347-364. http://dx.doi.org/10.1016/j.jretai.2014.01.002.

Kelleher, C., \& Peppard, J. (2011). Consumer experience of value creation-a phenomenological perspective. (ACR European Advances).

Kemp, E. A., Borders, A. L., Anaza, N., \& Johnston, W. J. (2018). The heart in organizational buying: Marketers' understanding of emotions and decision-making of 
buyers. Journal of Business \& Industrial Marketing, 33(1), 19-28. http://dx.doi.org/10. 1108/JBIM-06-2017-0129.

Keränen, J., \& Jalkala, A. (2013). Towards a framework of customer value assessment in B2B markets: An exploratory study. Industrial Marketing Management, 42(8), 1307-1317. http://dx.doi.org/10.1016/j.indmarman.2013.06.010.

Keränen, J., Piirainen, K. A., \& Salminen, R. T. (2012). Systematic review on B2B branding: Research issues and avenues for future research. The Journal of Product and Brand Management, 21(6), 404-417. http://dx.doi.org/10.1108/ 10610421211264892

Kilian, K. (2009). Experiential marketing and brand experiences: A conceptual framework. In A. Lindgreen, J. Vanhamme, \& M. B. Beverland (Eds.). Memorable customer experiences: A research anthology (pp. 25-44). Farnham: Gower.

Kirchgeorg, M., Springer, C., \& Ermer, B. (2012). Brand Lands - Inszenierung begehbarer Erlebniswelten für den Kunden. In M. Bruhn, \& K. Hadwich (Eds.). Customer Experience: Forum Dienstleistungsmanagement (pp. 296-316). Wiesbaden: Gabler Verlag.

Kirchgeorg, M., Springer, C., \& Kästner, E. (2010). Objectives for successfully participating in trade shows. Journal of Business \& Industrial Marketing, 25(1), 63-72. http:// dx.doi.org/10.1108/08858621011009164.

Kolb, D. A. (1984). Experiential learning: Experience as the source of learning and development. Englewood Cliffs NJ: Prentice-Hall.

Kotler, P. (1973). Atmospherics as a marketing tool. Journal of Retailing, 49(4), 48-64.

Kotler, P., \& Pfoertsch, W. (2007). Being known or being one of many: The need for brand management for business-to-business (B2B) companies. Journal of Business \& Industrial Marketing, 22(6), 357-362.

Kotler, P., Pfoertsch, W., \& Michi, I. (2006). B2B brand management. Berlin, New York: Springer.

Kozinets, R. V., Sherry, J. F., Jr., Storm, D., Duhachek, A., Nuttavuthisit, K., \& DeBerrySpence, B. (2004). Ludic agency and retail spectacle. Journal of Consumer Research, 31(3), 658-672. http://dx.doi.org/10.1086/425101.

Kozinets, R. V., Sherry, J. F., Jr., DeBerry-Spence, B., Duhachek, A., Nuttavuthisit, K., \& Storm, D. (2002). Themed flagship brand stores in the new millennium: Theory, practice, prospects. Journal of Retailing, 78(1), 17-29. http://dx.doi.org/10.1016/ S0022-4359(01)00063-X.

Kranzbühler, A.-M., Kleijnen, M. H., Morgan, R. E., \& Teerling, M. (2018). The multilevel nature of customer experience research: An integrative review and research agenda. International Journal of Management Reviews, 20(2), 433-456. http://dx.doi.org/10. 1111/ijmr.12140.

Kuhn, K. L., Alpert, F., \& Pope, N. K. L. (2008). An application of Keller's brand equity model in a B2B context. Qualitative Market Research: An International Journal, 11(1), 40-58. http://dx.doi.org/10.1108/13522750810845540.

Leek, S., \& Christodoulides, G. (2011). A literature review and future agenda for B2B branding: Challenges of branding in a B2B context. Industrial Marketing Management, 40(6), 830-837. http://dx.doi.org/10.1016/j.indmarman.2011.06.006.

Leek, S., \& Christodoulides, G. (2012). A framework of brand value in B2B markets: The contributing role of functional and emotional components. Industrial Marketing Management, 41(1), 106-114. http://dx.doi.org/10.1016/j.indmarman.2011.11.009.

Leischnig, A., \& Enke, M. (2011). Brand stability as a signaling phenomenon - An empirical investigation in industrial markets. Industrial Marketing Management, 40(7), 1116-1122. http://dx.doi.org/10.1016/j.indmarman.2011.09.001.

Lemon, K. N., \& Verhoef, P. C. (2016). Understanding customer experience throughout the customer journey. Journal of Marketing, 80(6), 69-96. http://dx.doi.org/10.1509/ jm.15.0420.

Lilien, G. L. (2016). The B2B knowledge gap. International Journal of Research in Marketing 33(3), 543-556. http://dx.doi.org/10.1016/j.ijresmar.2016.01.003.

Lindgreen, A. (2012). Value in business and industrial marketing. Industrial Marketing Management, 41(1), 4-7. http://dx.doi.org/10.1016/j.indmarman.2011.11.006.

Lindgreen, A., Beverland, M. B., \& Farrelly, F. (2010). From strategy to tactics: Building, implementing, and managing brand equity in business markets. Industrial Marketing Management, 39(8), 1223-1225. http://dx.doi.org/10.1016/j.indmarman.2010.02. 018.

Lindgreen, A., Hingley, M. K., Grant, D. B., \& Morgan, R. E. (2012). Value in business and industrial marketing: Past, present, and future. Industrial Marketing Management, 41(1), 207-214. http://dx.doi.org/10.1016/j.indmarman.2011.11.025.

Lusch, R. F., Vargo, S. L., \& O'Brien, M. (2007). Competing through service: Insights from service-dominant logic. Journal of Retailing, 83(1), 5-18. http://dx.doi.org/10.1016/ j.jretai.2006.10.002

Lynch, J., \& Chernatony, L.d. (2007). Winning hearts and minds: Business-to-business branding and the role of the salesperson. Journal of Marketing Management, 23(1-2), 123-135. http://dx.doi.org/10.1362/026725707X178594.

Lynch, J., \& de Chernatony, L. (2004). The power of emotion: Brand communication in business-to-business markets. Journal of Brand Management, 11(5), 403-419. http:// dx.doi.org/10.1057/palgrave.bm.2540185.

Maclaran, P., \& Brown, S. (2005). The center cannot hold: Consuming the utopian marketplace. Journal of Consumer Research, 32(2), 311-323. http://dx.doi.org/10.1086/ 432240.

Manlow, V., \& Nobbs, K. (2013). Form and function of luxury flagships: An international exploratory study of the meaning of the flagship store for managers and customers. Journal of Fashion Marketing and Management, 17(1), 49-64. http://dx.doi.org/10. 1108/13612021311305137.

Mathwick, C., Malhotra, N., \& Rigdon, E. (2001). Experiential value: Conceptualization, measurement and application in the catalog and internet shopping environment. Journal of Retailing, 77(1), 39-56. http://dx.doi.org/10.1016/S0022-4359(00) 00045-2.

Mayer, H. O. (2012). Interview und schriftliche Befragung: Grundlagen und Methoden empirischer Sozialforschung (6., überarbeitete Auflage). München: Oldenbourg.
Mayring, P. (2014). Qualitative content analysis: Theoretical foundation, basic procedures and software solution. Klagenfurt. Retrieved from http://nbn-resolving.de/ urn:nbn:de:0168-ssoar-395173.

McKechnie, S., \& Tynan, C. (2008). Halloween in a material world: Trick or treat? Journal of Marketing Management, 24(9-10), 1011-1023. http://dx.doi.org/10.1362/ 026725708X382028.

Mehrabian, A., \& Russell, J. A. (1974). An approach to environmental psychology. Cambridge Mass. u.a: MIT Press.

Mencarelli, R., \& Rivière, A. (2015). Perceived value in B2B and B2C. Marketing Theory, 15(2), 201-220. http://dx.doi.org/10.1177/1470593114552581.

Merleau-Ponty, M. (1962). Phenomenology of perception. trans. Colin SmithLondon: Routledge and Kegan Paul.

Michell, P., King, J., \& Reast, J. (2001). Brand values related to industrial products. Industrial Marketing Management, 30(5), 415-425. http://dx.doi.org/10.1016/S00198501(99)00097-8.

Mikunda, C. (2004). Brand lands, hot spots \& cool spaces.: Welcome to the third place and the total marketing experience. London, Sterling, VA: Kogan Page.

Mitchell, M. A., \& Orwig, R. A. (2002). Consumer experience tourism and brand bonding. The Journal of Product and Brand Management, 11(1), 30-41. http://dx.doi.org/10. $1108 / 10610420210419531$.

Mitchell, V.-W., Schlegelmilch, B. B., \& Mone, S.-D. (2016). Why should I attend? The value of business networking events. Industrial Marketing Management, 52, 100-108 http://dx.doi.org/10.1016/j.indmarman.2015.05.014.

Mora Cortez, R., \& Johnston, W. J. (2017). The future of B2B marketing theory: A historical and prospective analysis. Industrial Marketing Management, 66, 90-102. http:// dx.doi.org/10.1016/j.indmarman.2017.07.017.

Mudambi, S. (2002). Branding importance in business-to-business markets: Three buyer clusters. Industrial Marketing Management, 31(6), 525-533. http://dx.doi.org/10. 1016/S0019-8501(02)00184-0.

Mudambi, S. M., Doyle, P., \& Wong, V. (1997). An exploration of branding in industrial markets. Industrial Marketing Management, 26(5), 433-446. http://dx.doi.org/10. 1016/S0019-8501(96)00151-4.

Noë, A. (2006). Action in perception. Representation and mind(1. MIT Press paperback ed.). Cambridge, Mass: MIT Press.

O'Dell, T. (2010). Experiencescapes: Blurring borders and testing connections. In T. O'Dell (Ed.). Experiencescapes: Tourism, culture and economy (pp. 11-33). ( $1^{\text {st }}$ ed.). Frederiksberg: Copenhagen Business School Press.

Ohnemus, L. (2009). B2B branding: A financial burden for shareholders? Business Horizons, 52(2), 159-166. http://dx.doi.org/10.1016/j.bushor.2008.10.004.

Opaschowski, H. W. (2000). Kathedralen des 21. Jahrhunderts: Erlebniswelten im Zeitalter der Eventkultur (1. Aufl). Hamburg: Germa Press.

Österle, B., Kuhn, M., \& Henseler, J. (2016). An inquiry into brand worlds in industrial marketing. IMP group, Poznan University of Economics and Business. 32nd IMP Conference, Poznan.

Pine, B. J., \& Gilmore, J. H. (1999). The experience economy: Work is theatre \& every business a stage. Boston: Harvard Business School Press.

Plutchik, R. (1980). A general psychoevolutionary theory of emotion. Theories of Emotion, 1(3-31), 4.

Poulsson, S. H., \& Kale, S. H. (2004). The experience economy and commercial experiences. The Marketing Review, 4(3), 267-277. http://dx.doi.org/10.1362/ 1469347042223445.

Prahalad, C. K., \& Ramaswamy, V. (2004). Co-creation experiences: The next practice in value creation. Journal of Interactive Marketing, 18(3), 5-14. http://dx.doi.org/10. 1002/dir.20015.

Richins, M. L. (1997). Measuring emotions in the consumption experience. Journal of Consumer Research, 24(2), 127-146. http://dx.doi.org/10.1086/209499.

Riewoldt, O. (2002). Brandscaping: Worlds of experience in retail design. Erlebnisdesign für EinkaufsweltenBasel, Boston, MA: Birkhauser-Publishers for Architecture.

Rinallo, D., Borghini, S., \& Golfetto, F. (2010). Exploring visitor experiences at trade shows. Journal of Business \& Industrial Marketing, 25(4), 249-258. http://dx.doi.org/ 10.1108/08858621011038207.

Sánchez, J., Callarisa, L., Rodríguez, R. M., \& Moliner, M. A. (2006). Perceived value of the purchase of a tourism product. Tourism Management, 27(3), 394-409. http://dx. doi.org/10.1016/j.tourman.2004.11.007.

Saunders, J. A., \& Watt, F. (1979). Do brand names differentiate identical industrial products? Industrial Marketing Management, 8(2), 114-123. http://dx.doi.org/10 1016/0019-8501(79)90051-8.

Schmitt, B. H. (1999a). Experiential marketing. Journal of Marketing Management 15(1-3), 53-67. http://dx.doi.org/10.1362/026725799784870496.

Schmitt, B. H. (1999b). Experiential marketing: How to get customers to sense, feel, think, act and relate to your company and brands. New York NY: Free Press.

Schmitt, B. H., \& Zarantonello, L. (2013). Consumer experience and experiential marketing: A critical review. In N. K. Malhotra (Vol. Ed.), Review of marketing research. Review of marketing research. Vol. 10. Review of marketing research. Review of marketing research (pp. 25-61). Emerald Group Publishing Limited. http://dx.doi.org/10.1108/ S1548-6435(2013)0000010006.

Schulze, G. (2005). The experience society. London: SAGE.

Seyedghorban, Z., Matanda, M. J., \& LaPlaca, P. (2016). Advancing theory and knowledge in the business-to-business branding literature. Journal of Business Research, 69(8), 2664-2677. http://dx.doi.org/10.1016/j.jbusres.2015.11.002.

Sherry, J. F., Jr., Kozinets, R. V., Storm, D., Duhachek, A., Nuttavuthisit, K., \& DeBerrySpence, B. (2001). Being in the zone: Staging retail theater at ESPN zone Chicago. Journal of Contemporary Ethnography, 30(4), 465-510. http://dx.doi.org/10.1177/ 089124101030004005

Sherry, J. F., Jr. (1998). The soul of the company store: Nike Town Chicago and the emplaced brandscape. In J. F. SherryJr. (Ed.). Servicescapes: The concept of place in 
contemporary markets (pp. 109-146). Lincolnwood, Ill: NTC Business Books.

Shipley, D., \& Howard, P. (1993). Brand-naming industrial products. Industrial Marketing Management, 22(1), 59-66. http://dx.doi.org/10.1016/0019-8501(93)90021-X.

Sinclair, S. A., \& Seward, K. E. (1988). Effectiveness of branding a commodity product. Industrial Marketing Management, 17(1), 23-33. http://dx.doi.org/10.1016/00198501(88)90023-5.

Sweeney, J. C., \& Soutar, G. N. (2001). Consumer perceived value: The development of a multiple item scale. Journal of Retailing, 77(2), 203-220. http://dx.doi.org/10.1016/ S0022-4359(01)00041-0.

Trevinal, A. M., \& Stenger, T. (2014). Toward a conceptualization of the online shopping experience. Journal of Retailing and Consumer Services, 21(3), 314-326. http://dx.doi. org/10.1016/j.jretconser.2014.02.009.

Tynan, C., \& McKechnie, S. (2009). Experience marketing: A review and reassessment. Journal of Marketing Management, 25(5-6), 501-517. http://dx.doi.org/10.1362/ 026725709 X461821.

Van Boven, L., \& Gilovich, T. (2003). To do or to have? That is the question. Journal of Personality and Social Psychology, 85(6), 1193-1202. http://dx.doi.org/10.1037/ 0022-3514.85.6.1193.

Van Dijk, J. (2018). Designing for embodied being-in-the-world: A critical analysis of the concept of embodiment in the design of hybrids. Multimodal Technologies and Interaction, 2(1), 1-21. http://dx.doi.org/10.3390/mti2010007.

Van Riel, A. C., de Mortanges, C. P., \& Streukens, S. (2005). Marketing antecedents of industrial brand equity: An empirical investigation in specialty chemicals. Industrial Marketing Management, 34(8), 841-847. http://dx.doi.org/10.1016/j.indmarman. 2005.01.006.

Vargo, S. L., \& Lusch, R. F. (2008). Service-dominant logic: Continuing the evolution. Journal of the Academy of Marketing Science, 36(1), 1-10. http://dx.doi.org/10.1007/ s11747-007-0069-6.

Varshneya, G., \& Das, G. (2017). Experiential value: Multi-item scale development and validation. Journal of Retailing and Consumer Services, 34, 48-57. http://dx.doi.org/ 10.1016/j.jretconser.2016.09.010.

Varshneya, G., Das, G., \& Khare, A. (2017). Experiential value: A review and future research directions. Marketing Intelligence \& Planning, 35(3), 339-357. http://dx.doi.
org/10.1108/MIP-05-2016-0075.

Verhoef, P. C., Lemon, K. N., Parasuraman, A., Roggeveen, A., Tsiros, M., \& Schlesinger, L. A. (2009). Customer experience creation: Determinants, dynamics and management strategies. Journal of Retailing, 85(1), 31-41.

Webb, B. (2012). A classification approach to flagship stores. In T. Kent, \& R. Brown (Eds.). Flagship marketing: Concepts and places (pp. 20-31). Routledge.

Webster, F. E., \& Keller, K. L. (2004). A roadmap for branding in industrial markets. Journal of Brand Management, 11(5), 388-402. http://dx.doi.org/10.1057/palgrave. bm. 2540184.

Wise, R., \& Zednickova, J. (2009). The rise and rise of the B2B brand. Journal of Business Strategy, 30(1), 4-13. http://dx.doi.org/10.1108/02756660910926911.

Withagen, R., de Poel, H. J., Araújo, D., \& Pepping, G.-J. (2012). Affordances can invite behavior: Reconsidering the relationship between affordances and agency. New Ideas in Psychology, 30(2), 250-258. http://dx.doi.org/10.1016/j.newideapsych.2011.12. 003.

Wood, E. H. (2009). Evaluating event marketing: Experience or outcome? Journal of Promotion Management, 15(1-2), 247-268. http://dx.doi.org/10.1080/ 10496490902892580.

Woodruff, R. B. (1997). Customer value: The next source for competitive advantage. Journal of the Academy of Marketing Science, 25(2), 139-153. http://dx.doi.org/10. 1007/BF02894350.

Yakhlef, A. (2015). Customer experience within retail environments: An embodied, spatial approach. Marketing Theory, 15(4), 545-564. http://dx.doi.org/10.1177/ 1470593115569016.

Zablah, A. R., Brown, B. P., \& Donthu, N. (2010). The relative importance of brands in modified rebuy purchase situations. International Journal of Research in Marketing, 27(3), 248-260. http://dx.doi.org/10.1016/j.ijresmar.2010.02.005.

Zarantonello, L., \& Schmitt, B. H. (2013). The impact of event marketing on brand equity: The mediating roles of brand experience and brand attitude. International Journal of Advertising, 32(2), 255-280. http://dx.doi.org/10.2501/IJA-32-2-255-280.

Zentes, J., Ney, B., \& Keßler, D. (2014). Markenwelten: Multisensualität und Markenidentität. Saarbrücken: H.I.MA., Inst. für Handel \& Internationales Marketing. 